\title{
RADIOCARBON DATING OF THE WESTERN EUROPEAN NEOLITHIC: COMPARISON OF THE DATES ON BONES AND DATES ON CHARCOALS
}

\author{
Anthony Denaire \\ Antea-Archéologie, Habsheim, UMR 7044 Strasbourg, France. Email: anthony.denaire@neuf.fr.
}

\begin{abstract}
The subject of this article is the radiocarbon dating on bones in the western European Neolithic. By gathering ${ }^{14} \mathrm{C}$ dates for 2 examples, one chosen in the middle Neolithic of the Rhine region and the other in the end of the early Neolithic in the same region and in the Paris Basin, a significant gap appears between the sum probabilities of dates on charcoals and the ones obtained with bones. A comparison between these results with the few available dendrochronological dates shows that dates on bones seem too young, while the sequence based on charcoals fits. The existence of too-young ${ }^{14} \mathrm{C}$ dates of bones is not new: this phenomenon was already indicated in previous studies. Most explanations agree that there was a source of contamination, during the sample's burial or its treatment in laboratory. These examples illustrate that consequences can be heavy on a chronology built, partly or entirely, on ${ }^{14} \mathrm{C}$ dates of bones.
\end{abstract}

\section{INTRODUCTION}

The purpose of this paper is to investigate the validity of radiocarbon dates on bones in the western European Neolithic. To treat this question, 2 examples are presented, the former chosen in the middle Neolithic of the Rhine region, the latter taken in the end of the early Neolithic in the Paris Basin and the Rhine Valley. The aim is less to discuss the dating of these contexts than to underline the existence in both examples of series of ${ }^{14} \mathrm{C}$ dates on bones that are too young when compared with the results given by the dendrochronology, whereas the dates on charcoals seem to agree.

\section{THE MIDDLE NEOLITHIC}

The starting point of this subject leans on an aspect of a thesis devoted to the archaeological cultures of the middle Neolithic in regions of the Rhine, namely the cultures of Hinkelstein, Grossgartach, and Rössen, and the group of Bischheim (Denaire 2009).

Before considering the ${ }^{14} \mathrm{C}$ dating, it would be useful to briefly discuss these cultures. Chronologically, they take place between the end of the 6th and the first half of the 5th millennium cal BC (Figure 1). During the entire last century, the chronological question was the subject of bitter debate, especially regarding the order in which these cultures succeed one another. The order that is accepted today is based on archaeological data (Meier-Arendt 1969). On this point, ${ }^{14} \mathrm{C}$ dating has played no role.

It is possible to claim that the Hinkelstein culture is largely contemporary with the end of the early Neolithic based on the pits of Forchheim in the southern of Baden region (Stöckl 1994) or the site of Köln-Lindenthal in North Rhineland-Westphalia (Buttler 1935), in which Hinkelstein potsherds were found in association with late Linearbandkeramik ones, as well as the famous grave of Vickletice in Bohemia, in which was found pottery of the Stroke-Ornamented ware culture and 2 other potteries imported from the Rhine Valley. One had typical decoration from the end of the Linearbandkeramik, the other had a decoration similar to Hinkelstein work (Zapotocka 1986). Moreover, Hinkelstein was previously considered as one of the groups at the end of Linearbandkeramik (Meier-Arendt 1975) before being recently categorized as a separate archaeological culture (Spatz 1999).

Studies of the ceramic works (Figure 2), the finery, and the funerary practices have shown that the cultures of Hinkelstein, Grossgartach, and Rössen and the group of Bischheim are genetically 


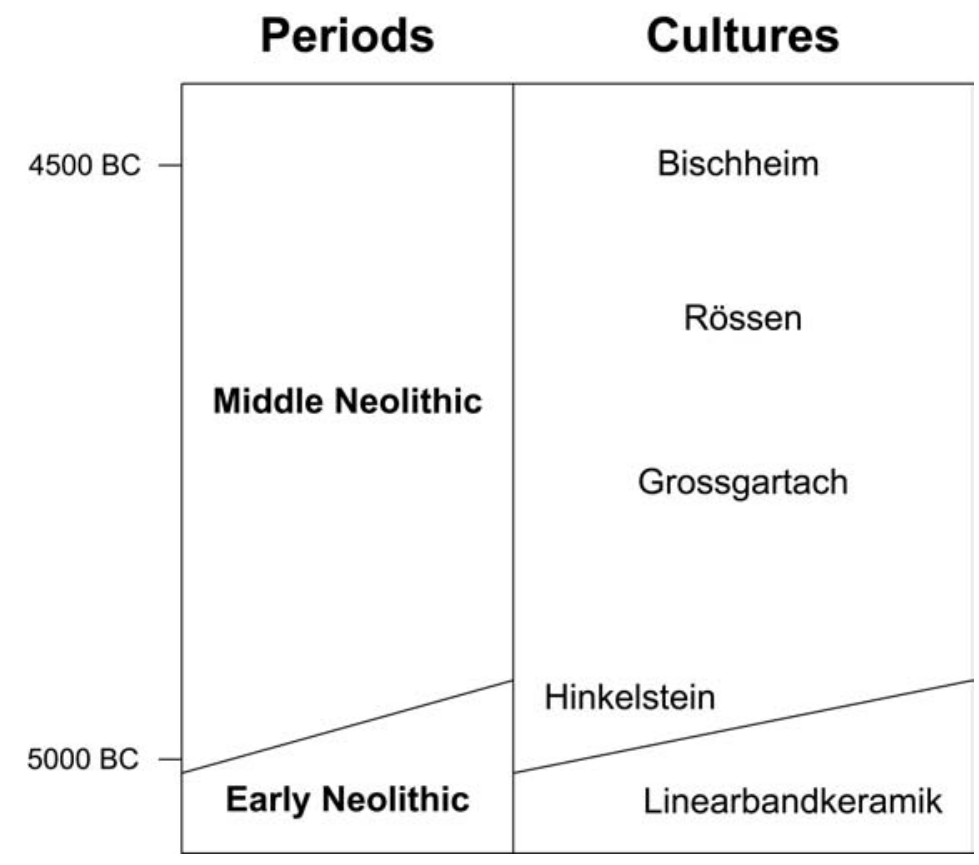

Figure 1 Simplified chronological table of the middle Neolithic for the Rhine region

linked. In addition, stratigraphies in the region of Lake Constance (Dieckmann 1987) and many recuts of pits and graves, especially in Alsace (Denaire 2009), provide proof of the succession Hinkelstein-Grossgartach-Rössen-Bischheim.

More than 170 Hinkelstein sites have been counted (Denaire 2009). Most are located in the Middle Rhine, the Palatinate, the region of the Neckar and the Wetterau, and a few in the north of Alsace, southern Baden, and the Lake Constance region (Figure 3A). This culture is especially known through its graveyards in the Palatinate, like Worms-Rheingewann and Rheindürkheim (MeierArendt 1975). Settlements are still unknown, with just a few domestic pits found. During the Grossgartach, the territory grew in a southern direction, to the Upper Rhine plain, the Lower Rhine, and the Moselle Valley as well as central Germany (Figure 3B). About 600 sites are indicated in this area. The quality of the documentation increases also, with large excavations on villages with buildings in the Lower Rhine and with important cemeteries, particularly in Alsace. During the Rössen period, the number of sites remains approximately the same (about 600). The area distribution evolves little, except in central Germany and the Lower Rhine where the density of sites rises (Figure 4A). If only a few funeral contexts were studied, several settlements with houses and enclosures were excavated. The Bischheim is less well known, with 120 sites. The main reason is the difficulty to find settlements of this group: houses are smaller and fewer pits have been dug. Regarding the geographical aspects, Bischheim marks a change with the colonization of the Paris Basin (Figure 4B).

After this short presentation of the archaeological context, let us consider the dating of these 4 cultures. They have together a duration of more than $500 \mathrm{yr}$. For this resolution (>100 yr), it should be possible to work with ${ }^{14} \mathrm{C}$ dates. In total, $118{ }^{14} \mathrm{C}$ measurements were found in the literature for Hinkelstein, Grossgartach, Rössen, and Bischheim (see Table 1, in Appendix). Of course, it is understood that these dates cannot all be usable, and it is necessary to select reliable dates. The cri- 

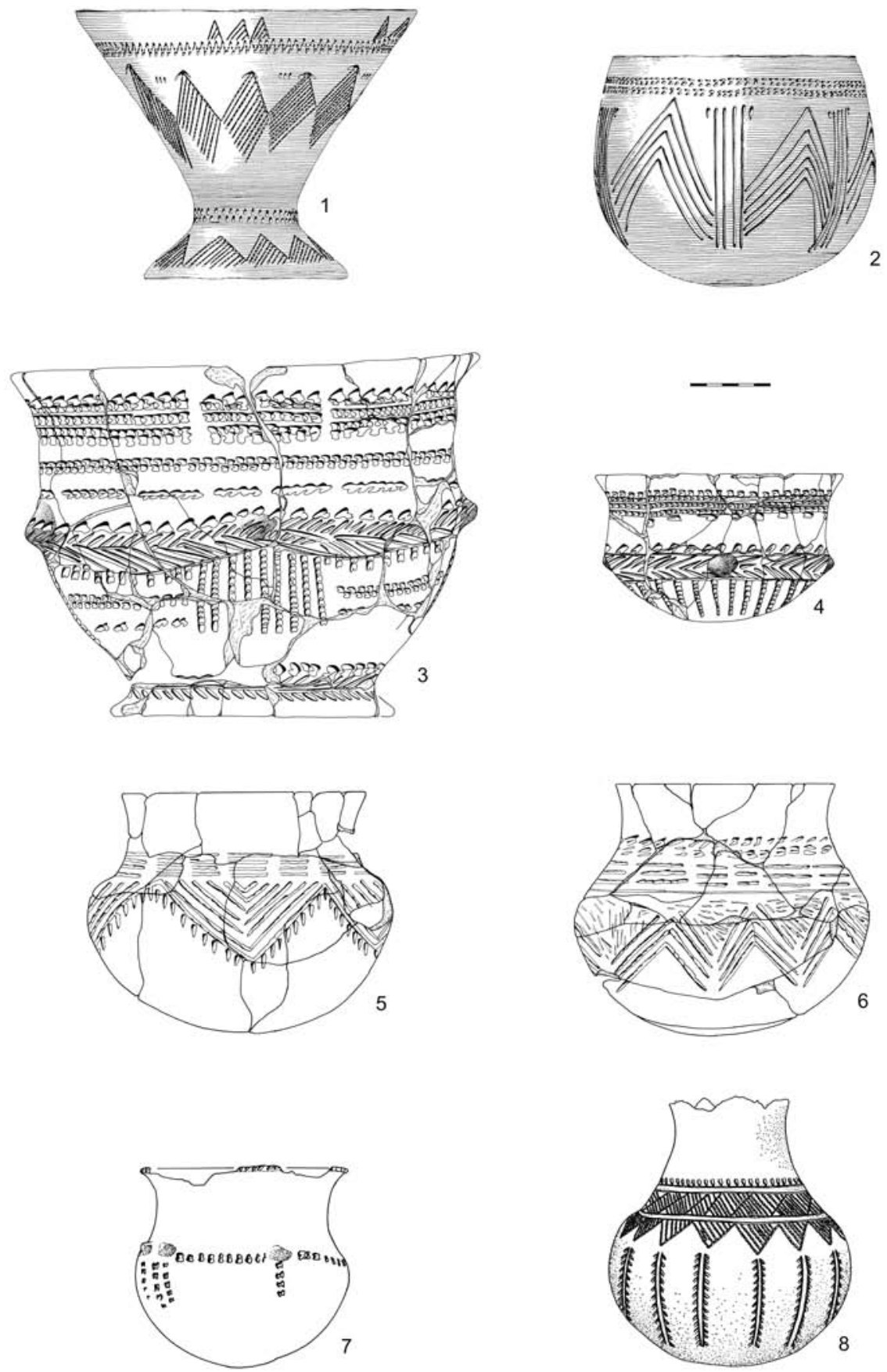

Figure 2 Selection of decorated potteries of the cultures of Hinkelstein (1-2), Grossgartach (34), Rössen (5-6) and Bischheim (7-8). 1-2 in Meier-Arendt 1975; 2-6 in Denaire 2009; 7-8 in Jeunesse et al. 2003.

teria are the following. The archaeological context must be certain, and the interval has to be smaller than $100 \mathrm{yr}(< \pm 100 \mathrm{yr}$ BP $)$. Finally, the dates affected by evidence of contamination, like the con- 

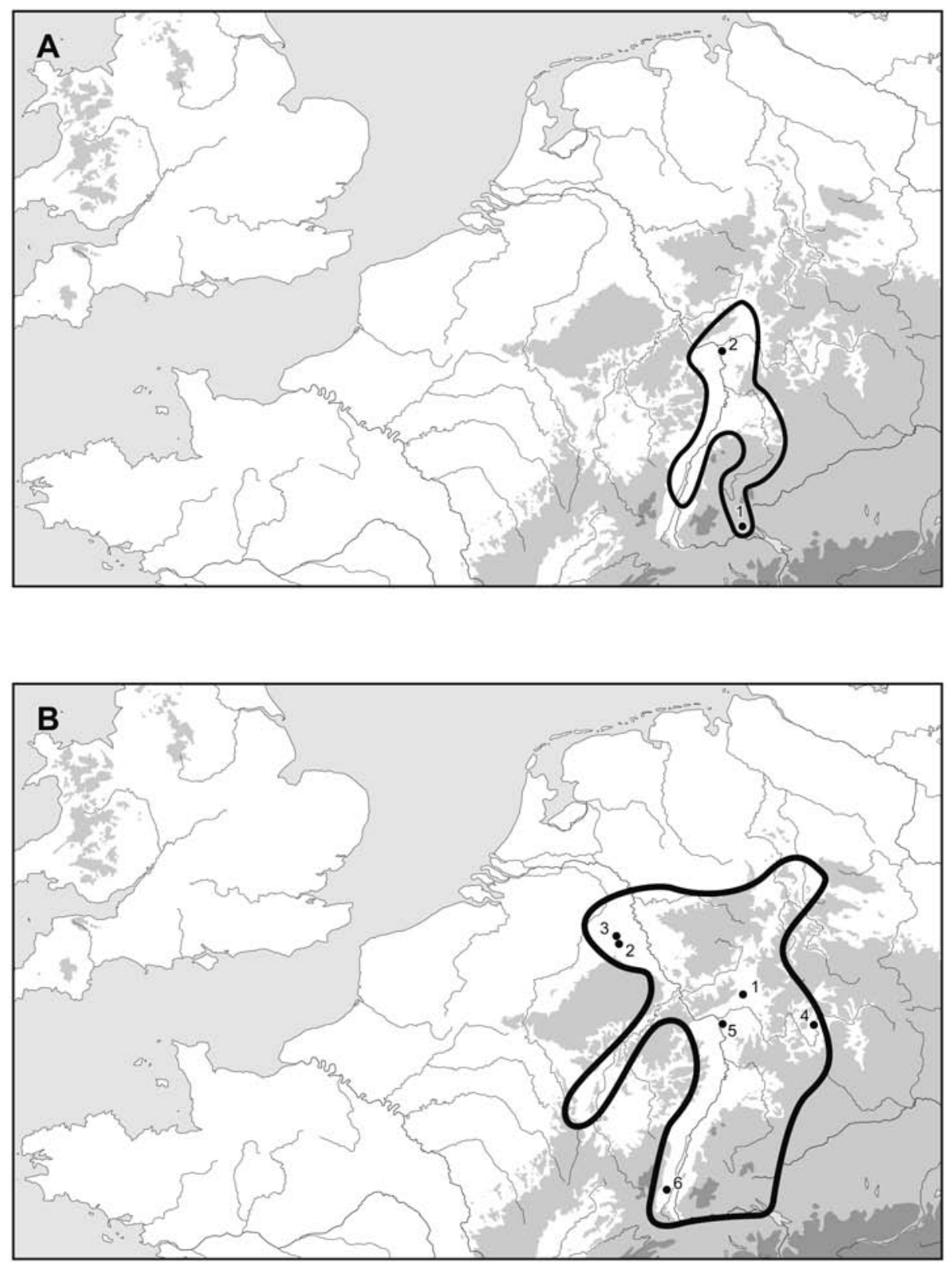

Figure 3 Distribution map of Hinkelstein (A) and Grossgartach (B). A: 1-Mülhausen, 2-Trebur; B: 1-Bad-Nauheim-Steinfurth, 2-Hambach 260, 3-Hasselweiler 2, 4-Schwanfeld, 5-Trebur, 6-Wettolsheim.

ventional measurements on human bones of Trebur, are excluded (Spatz 2001). For example, the 2 dates of Zizers, in the canton of Grisons, cannot be kept since the relation between the samples and Hinkelstein shards is not clear. Furthermore, this site is located more than $100 \mathrm{~km}$ from the southern limit of the distribution area for the Hinkelstein culture. It seems that we are not following the case of the Bischheim and Epirössen pottery found in Egolzwil settlements (Doppler 2007), but like the case depicted in Zurich-Mozartstrasse where Grossgartach shards were found in more recent layers than expected (Stöckli 1990). Thus, these ${ }^{14} \mathrm{C}$ samples have also been rejected. 

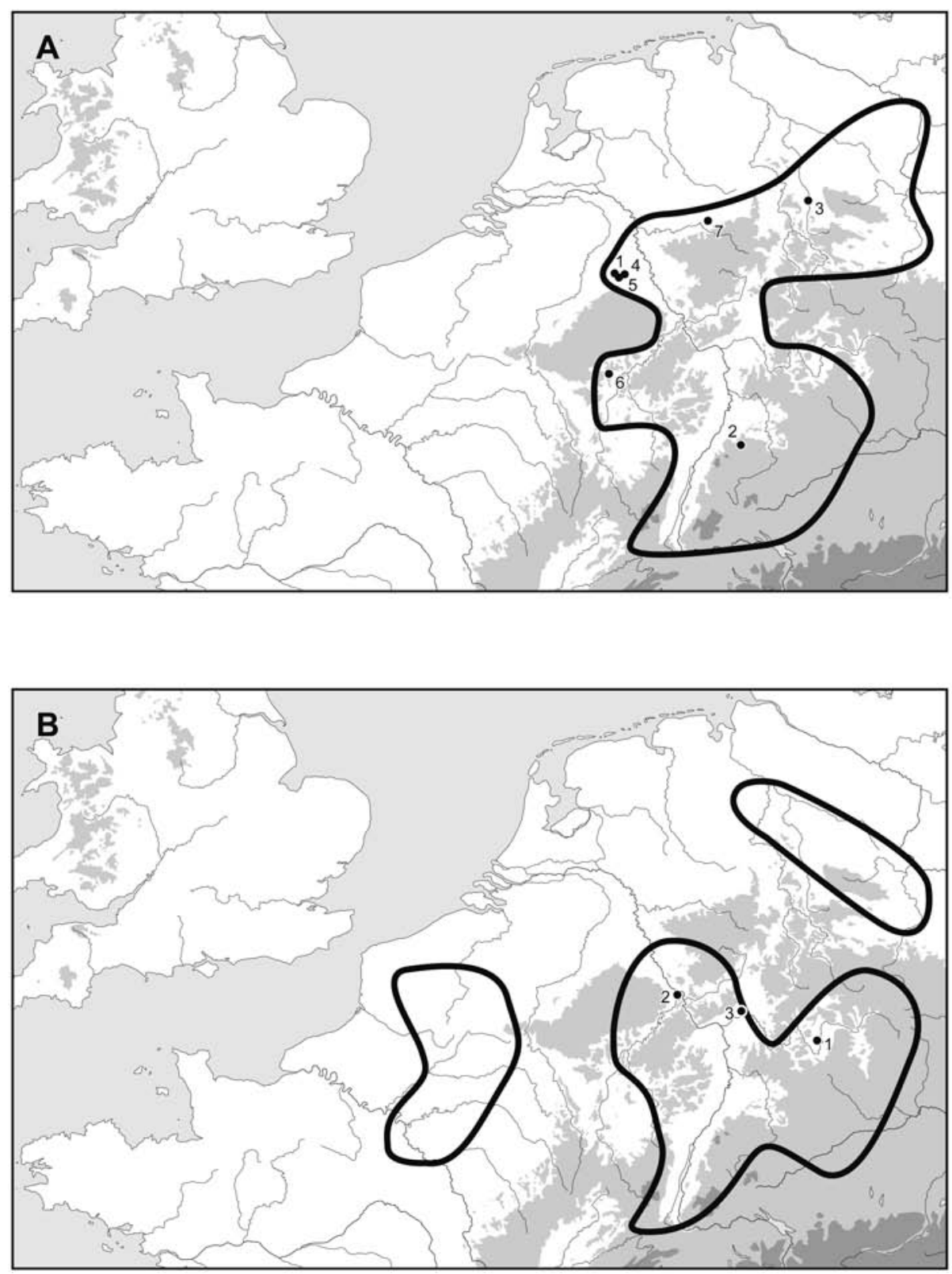

Figure 4 Distribution map of Rössen (A) and Bischheim (B). A: 1-Aldenhoen 1, 2-Deiringsen-Ruploch, 3Einbeck-Drüber, 4-Hambach 471, 5-Inden 1 and 3, 7-Waldbillig; B: 1-Dittelbach-Schernau, 2-Kärlich, 3Schwalheim.

From about 100 total dates, only 44 were selected: 8 for Hinkelstein, 12 for Grossgartach, 20 for Rössen, and 4 for the Bischheim. Within this selection, charcoal is the best represented material with about $70 \%$ of the samples, with most of the remaining samples from bone.

The sum of the probabilities of all the dates, on charcoals and bones, were calculated with the software OxCal 3.10 (Bronk Ramsey 1995, 2001) (Figure 5) and the IntCal04 calibration curve data 
(Reimer et al. 2004). The results must be analyzed. According to observations of the stratigraphies, Hinkelstein is really the first culture and Bischheim the last, but at the expected succession between Grossgartach and Roessen, the ${ }^{14} \mathrm{C}$ sets show a strict contemporaneousness. The phase model function of OxCal software applied on the same dates is of no help. Indeed, it reduces the chronological span of Grossgartach and Roessen to a few years.

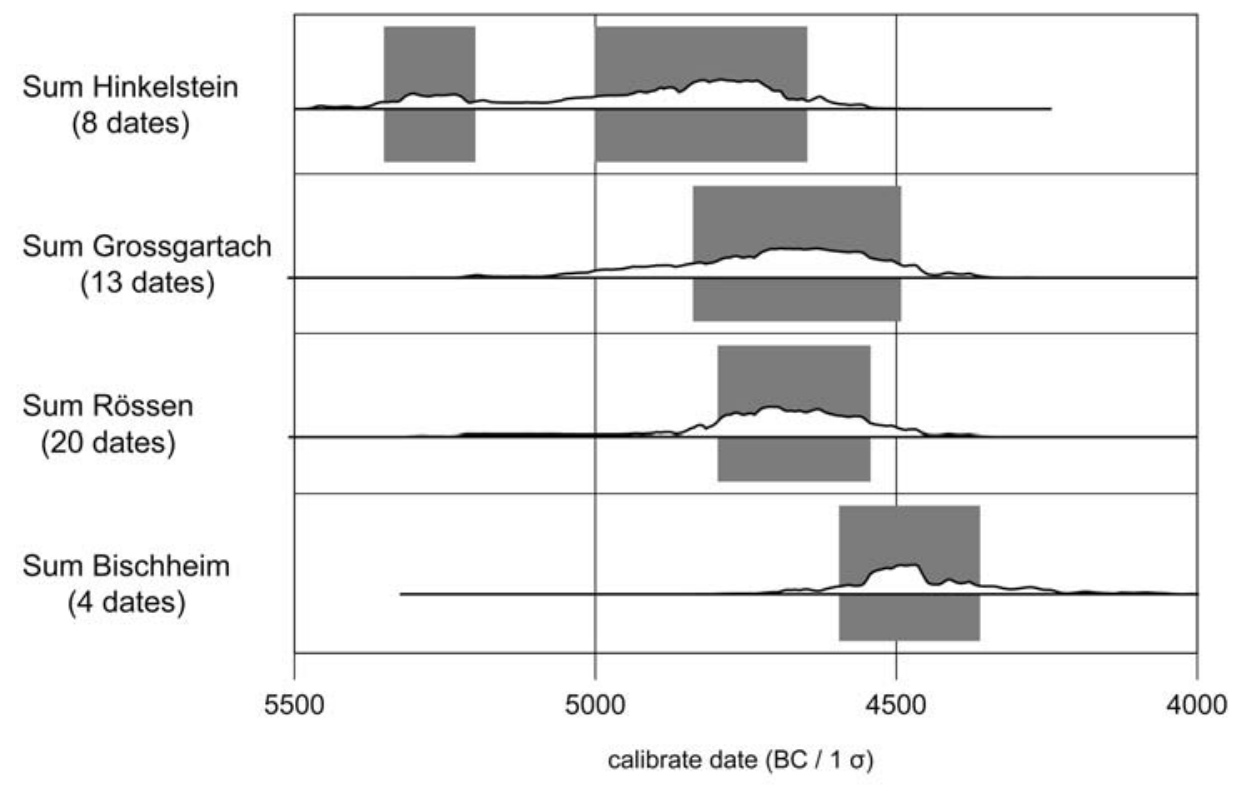

Atmospheric data from Reimer et al (2004); OxCal v3.10 Bronk Ramsey (2005); cub r:5 sd:12 prob usp[chron]

Figure $5{ }^{14} \mathrm{C}$ dating of Hinkelstein, Grossgartach, Rössen and Bischheim (all kind of sample). Sum of the probabilities calculated with the software OxCal 3.10.

However, if we sort the dates according to the sample material, the results are more in agreement with the stratigraphies. The sum of the probabilities for the dates on charcoals (Figure 6) shows a succession between Hinkelstein (5370-4990 cal BC, $1 \sigma$ ), Grossgartach (4900-4600 cal BC), Rössen (4790-4550 cal BC), and the group of Bischheim (4590-4360 cal BC). The partial overlap between Grossgartach and Rössen could be explained by the fact that the available dates of charcoals for Grossgartach concern, according to the ceramic decorations, a young phase of this culture. This succession is confirmed by the phase model function of OxCal, which places the transitions around 4900, 4830/4790, and 4595/4510 cal BC, respectively.

As for the dates on bones, only Hinkelstein and Grossgartach contain information; no measurement on bone is currently available for the Rössen and Bischheim contexts (Figure 7). The sum of the probabilities gives for Hinkelstein and Grossgartach a younger dating than those obtained with dates on charcoals (respectively, 4950-4610 and 4770-4460 cal BC).

It now remains to determine which series is the best to use, which one links best with the end of the early Neolithic and with the period following the Bischheim (the so-called epirössen horizon). Luckily, these 2 events are fixed by dendrochronological and ${ }^{14} \mathrm{C}$ dating. Thus, the date of the woodlined well of Erkelenz-Kückhoven (5057 $\pm 5 \mathrm{yr}$; Weiner 1998) allows to place the end of the early Neolithic at 5050-5000 cal BC. As the Hinkelstein is largely contemporary with the end of Linearbandkeramik, the sum of the probabilities should, logically, be mostly before the date supplied by 


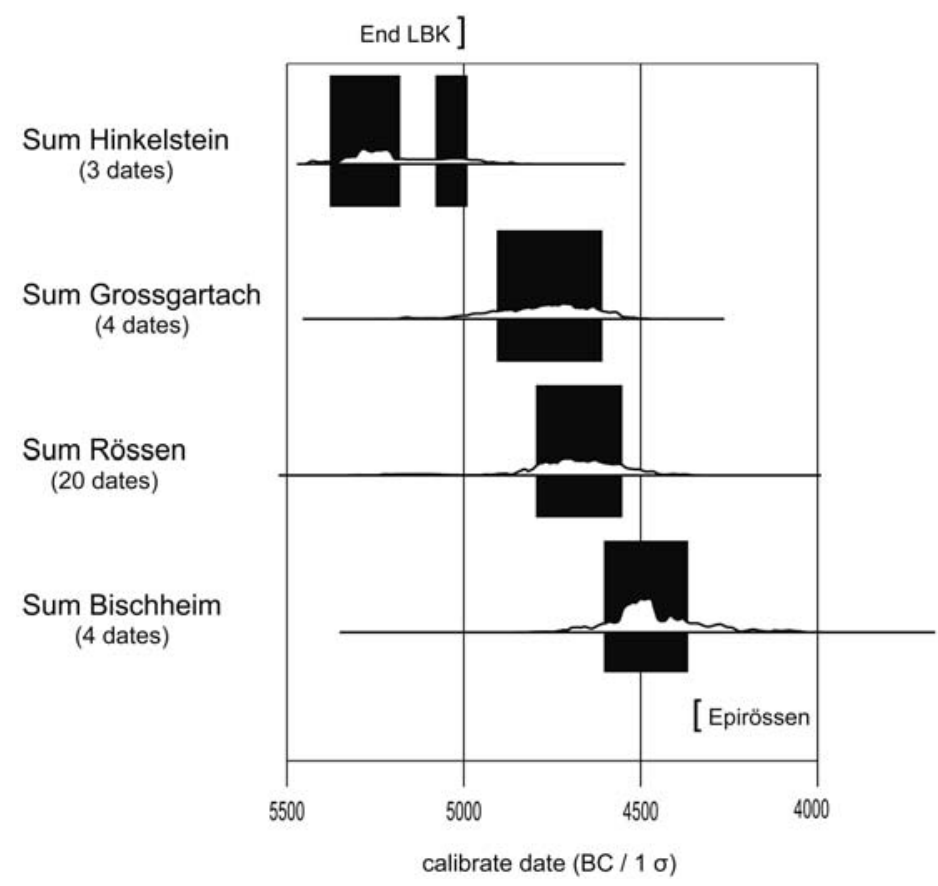

Figure $6{ }^{14} \mathrm{C}$ dating on charcoals of Hinkelstein, Grossgartach, Rössen, and Bischheim. Sum of the probabilities calculated with the software OxCal 3.10.

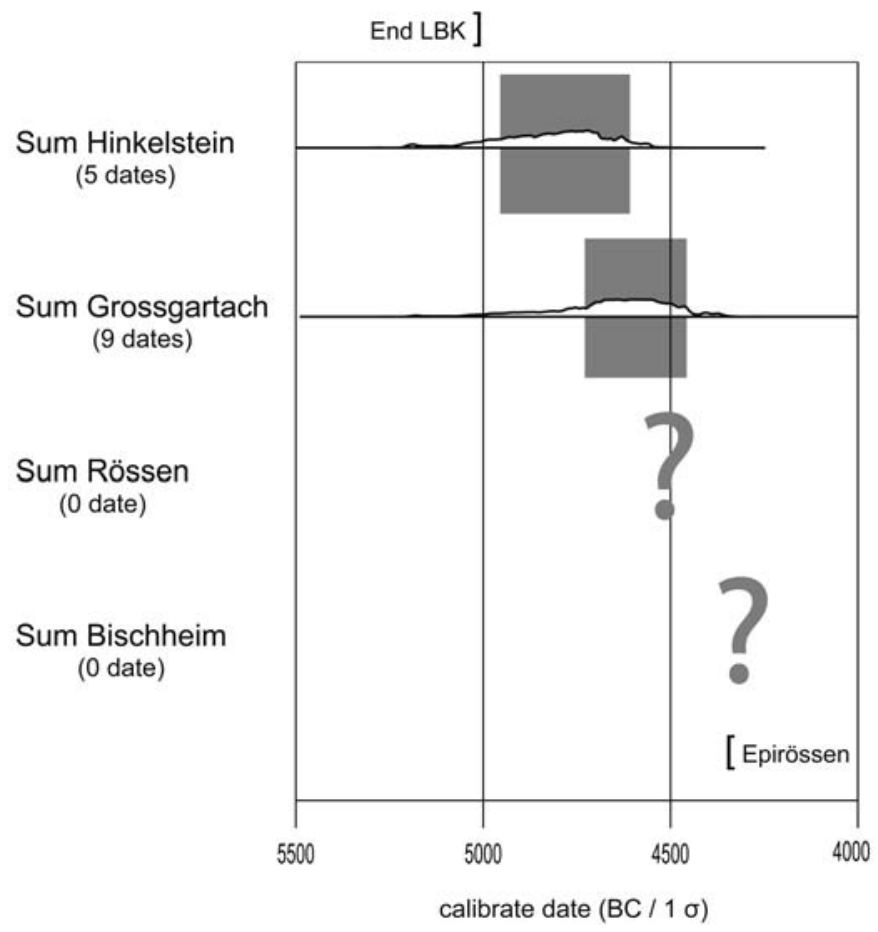

Figure $7{ }^{14} \mathrm{C}$ dating on bones of Hinkelstein, Grossgartach, Rössen, and Bischheim. Sum of the probabilities calculated with the software OxCal 3.10. 
the well of Kückhoven. By rejecting the dating of Hinkelstein after $4950 \mathrm{cal} \mathrm{BC}$, dates on bones do not agree with this chronological sketch, while those supplied charcoal measurements fit well (Figure 4). Available tree-ring and ${ }^{14} \mathrm{C}$ dates for the epirössen horizon place its beginnings towards 4350 cal BC at the latest (Jeunesse et al. 2003:146; Zeeb 1998:147-8). The dates on charcoals articulate well with this terminus (Figure 4). By rejecting dating of the Roessen and the Bischheim after 4500 cal BC, the dates on bone for Grossgartach leave too little span of time for these 2 cultures ( $<150 \mathrm{yr})$.

In conclusion, from this first example, it is necessary to emphasize that, contrary to what it is usually expected, the ${ }^{14} \mathrm{C}$ dates on charcoals agree well with the dendrochronology, while dates on bones seem too young.

\section{THE END OF THE LINEARBANDKERAMIK CULTURE}

The second example concerns the early Neolithic. It is not my ambition to tackle the difficult question of the ${ }^{14} \mathrm{C}$ dating of the Linearbandkeramik. I am only interested in the end of this culture, more particularly in the Paris Basin and regions of the Rhine, especially North Rhineland-Westphalia, the Middle Rhine, and the Palatinate, and the Neckar Valley (Figure 8). As recent studies support, the end of the Linearbandkeramik can be considered roughly contemporary in these regions (Lefranc 2007:227). A discussion remains concerning the very end of the Linearbandkeramik in the Paris Basin, called the RRBP final. Two different points of view exist. The first places the RRBP final before the Villeneuve-Saint-Germains (VSG) and the Augy-Sainte-Pallaye (ASP), 2 other cultures of the early Neolithic in the Paris Basin (Figure 9A; Dubouloz 2003). The second considers that the RRBP récent, the VSG, and the ASP are largely contemporaneous and rejects placing the RRBP final after them (Figure 9B; Jeunesse 1999). In this opinion, the end of the RRBP final could be synchronized with the beginning of the Grossgartach horizon. Considering the ${ }^{14} \mathrm{C}$ data, no difference exists between RRBP récent and final dates. As the context (récent or final) is not always indicated, both series were treated together.

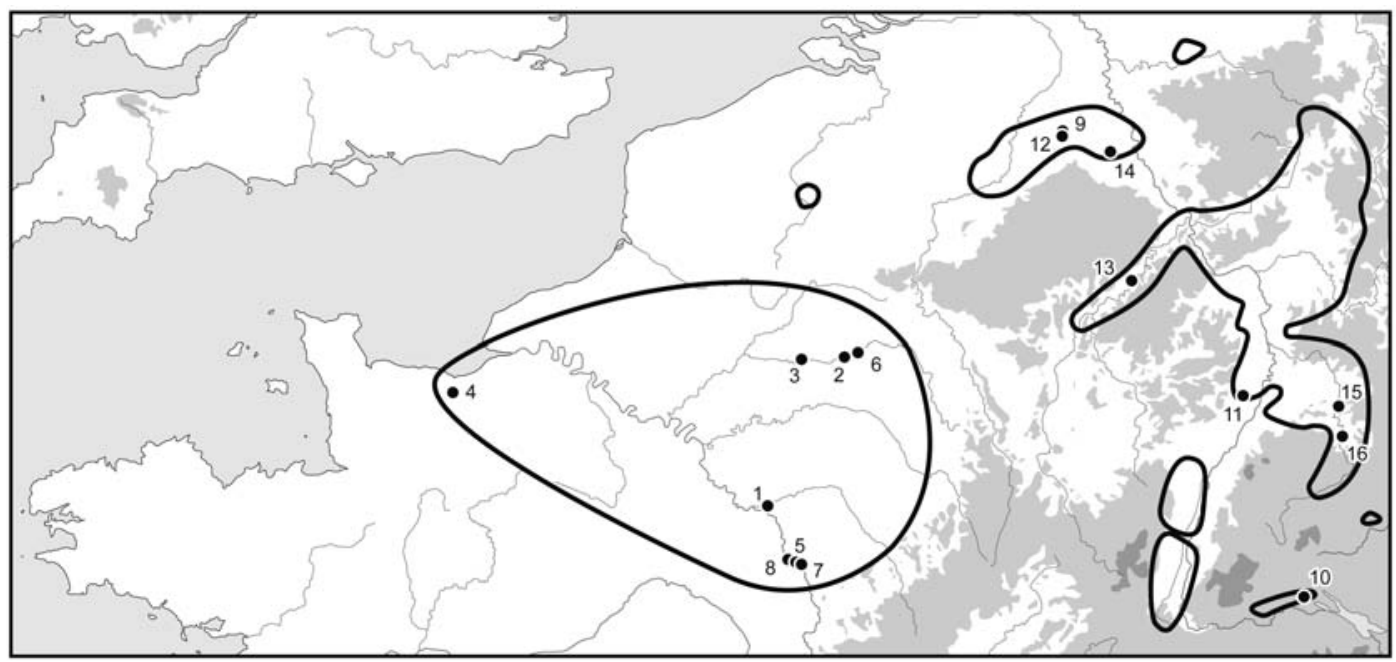

Figure 8 Distribution map of the regional groups of the Linearbandkeramik. A) Paris Basin: 1-Balloy, 2-Berry-au-Bac, 3Bucy-le-Long, 4-Colombelles, 5-Champlay, 6-Menneville, 7-Passy-sur-Yone, 8-Saint-Julien-du-Saut; B) regions of the Rhine: 9-Aldenhoven-Niedermerz 3, 10-Hilzingen, 11-Herxheim, 12-Langweiler 2, 3, 8 and 9, 13-Mering-Noviand, 14-Müddersheim, 15-Talheim, 16-Stuttgart-Mülhausen. 


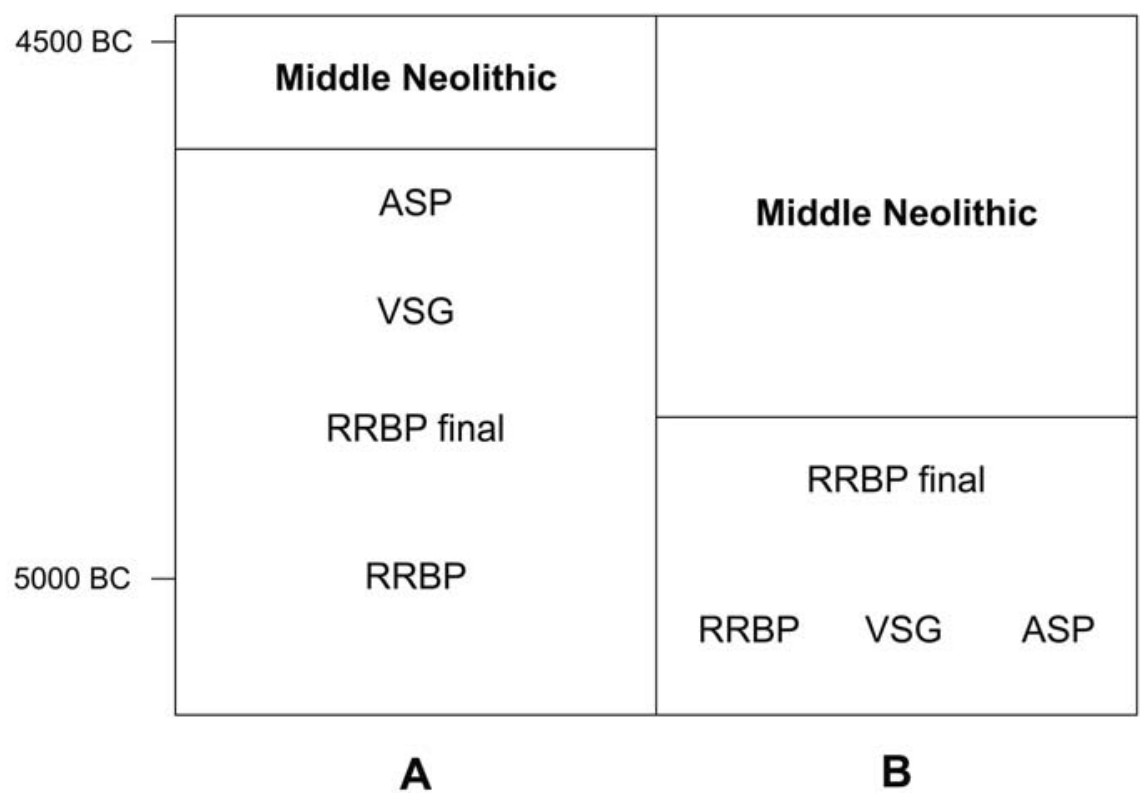

Figure 9 Simplified chronological table of the ancient Neolithic in the Paris Basin

The literature in these regions gives $119{ }^{14} \mathrm{C}$ dates for the end of Linearbandkeramik (Table 2, in Appendix). Of the 119, 67 were chosen as reliable, 51 for the regions of the Rhine and 16 for the Paris Basin. The used criteria of selection are the same that previously. This series of dates is dominated by measurements on bone in the Paris Basin, where only 3 dates on charcoals were able to be collected (site of Collombelles) and 3 other dates on crops and hazelnuts. In the regions of the Rhine, dates on bones are as numerous as ones on charcoal (with crops), respectively, 25 and 26 samples. The sum of the probabilities for all the dates gives about the same time span, except that the one for Paris Basin is a little wider (Figure 10).

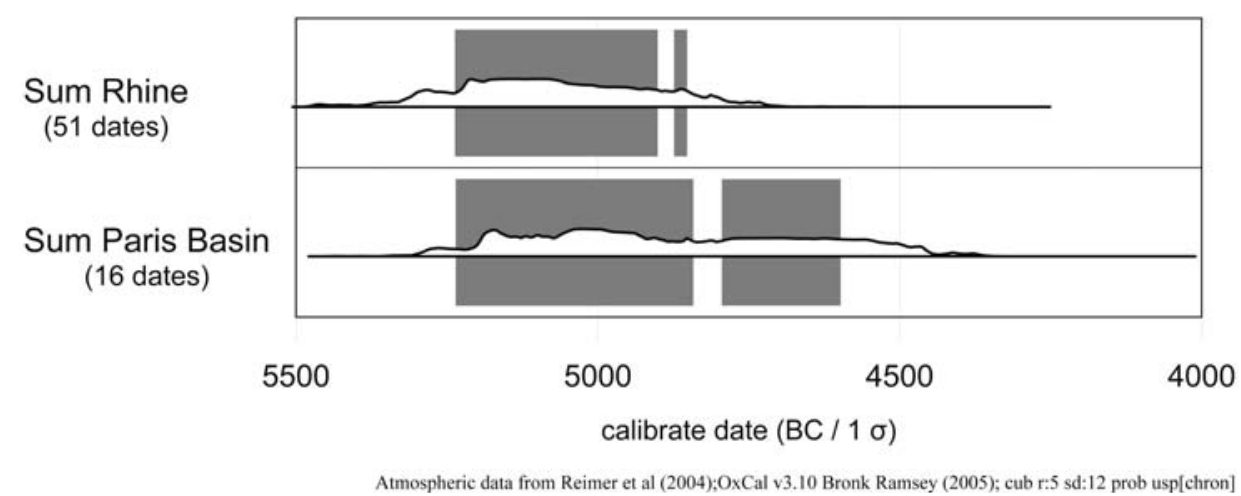

Figure $10{ }^{14} \mathrm{C}$ dating of the end of Linearbandkeramik in Paris Basin and the regions of the Rhine (all samples). Sum of the probabilities calculated with the software OxCal 3.10.

As in the previous example, we have separated the dates on bones from those on charcoals (Figure 11). In the Paris Basin and the Rhine region, the chronological interval is approximately the same, before 5000 cal BC. However, with only 6 dates on charcoal and crops, the series of Paris Basin can- 
not be compared with the Rhine results without restrictions. New dates are needed to confirm this observation.

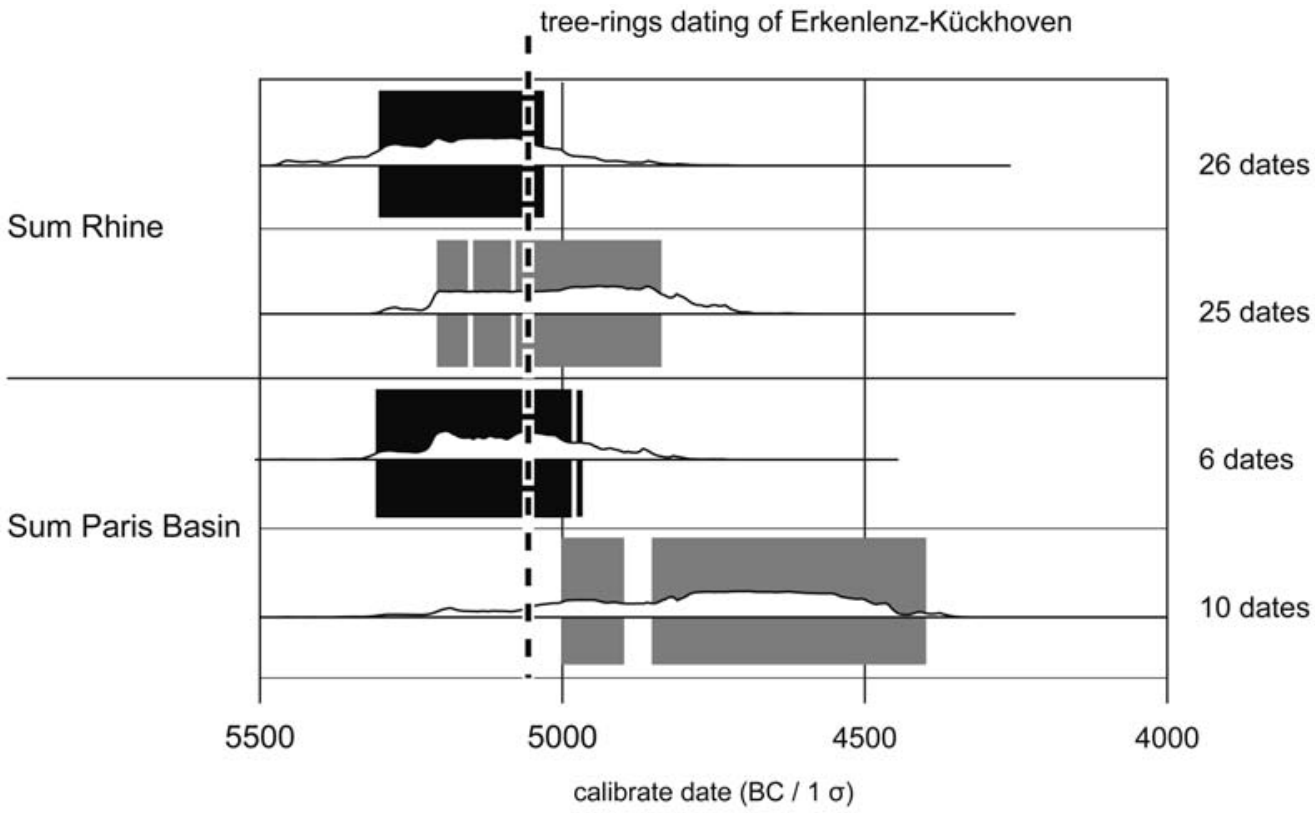

Atmospheric data from Reimer et al (2004);OxCal v3.10 Bronk Ramsey (2005); cub r:5 sd:12 prob usp[chron]

Charcoals $\quad$ Bones

Figure $11{ }^{14} \mathrm{C}$ dating on charcoals and bones of the end of Linearbandkeramik in Paris Basin and the regions of the Rhine. Sum of the probabilities calculated with the software OxCal 3.10.

The dates obtained on bones are again younger: 5210-5160, 5150-5090, and 5080-4840 cal BC for regions of the Rhine; 5000-4900 and 4850-4450 cal BC for the Paris Basin. In order the best series between these 2 examples, it is possible to lean again on the dendrochronological date of ErkenlenzKückhoven, which allows for the Rhineland to be placed at the end of Linearbandkeramik, towards 5000 cal BC (Spatz 2001). The series that fits best into this sketch-the one which is, for the main part, previous to this tree-ring date-is the series on charcoals, whereas the dates on bones seem too young (Figure 11).

Keeping in mind the discussion above on the relative chronology of the Paris Basin, and if we consider that the date of Erkenlenz could be a reference for this region, one is able to conclude that the dates on charcoals and crops fit well (they give the same result as in the regions of the Rhine); the dating on bones is once again for a large part too young. Even if we opt for a late position of the RRBP final in the chronology sequence, it is impossible to support that the end of the Linearbandkeramik takes place after $4800 \mathrm{cal}$ BC in the Paris Basin. The chronological span given by the bone measurements is largely younger: it is contemporaneous with the Rössen culture and a large part of the Bischheim group!

\section{CONCLUSION}

First, it is necessary to clarify the limits of the exercise in which we have engaged. Indeed, once the selection of dates is operated, each culture or phase is dated only by a few of measurements, which, 
furthermore, come from different regions (Figures 3, 4, and 8). Nothing allows us to prove that the chronology in these regions is strictly the same. Furthermore, a wide part of our argument is based on the tree-ring date of the Kückhoven well. It is not impossible that new dating will bring important modifications, which has already been the case for other contexts (Conscience 2001). We can also discuss the link between the wood-lined well and the shards. Despite these reservations, we can conclude that dates on bones seem too young while those on charcoals fit better. In the example of the middle Neolithic, it is impossible to consider the Grossgartach dates on bone as good ones: they do not leave enough time for the Rössen and Bischheim before the beginning of the epirössen groups.

It is difficult to generalize these observations in other Neolithic contexts: first, only a few contexts possess ${ }^{14} \mathrm{C}$ measurements on bones and charcoals as well as tree-ring dates; second, often it is obvious that dates on charcoals are really too old, influenced by the "old wood" effect. The purpose of this paper is not to reject ${ }^{14} \mathrm{C}$ dates on bones, which are often the only available kind of sample in Neolithic sites, but to stress that this material, whose life is shorter than most of trees' species, is not exempt of problems. Consequences can be heavy on a chronology built, partly or entirely, on ${ }^{14} \mathrm{C}$ dates of bones.

The existence of too-young ${ }^{14} \mathrm{C}$ dates on bones is not new: it has been indicated in archaeological literature on the Neolithic (Spatz 2001) and ancient prehistory (Higham et al. 2006). However, it seems that for the Neolithic, this phenomenon does not concern just 1 or 2 dates, but can affect several samples, with all the consequences that it can have on the construction of a chronology built, partly or entirely, on such dates. The explanations generally advanced discuss problems of contamination during the sample's burial (Spatz 2001) or its treatment in the laboratory (Bronk Ramsey et al. 2004). Moreover, it is regrettable that for most of the dates treated in this paper, no indication specifies the quality of the sample and the procedure followed by the laboratory. Finally, this problem underlines the need for a more intense interdisciplinary cooperation between dating laboratories and archaeologists.

\section{REFERENCES}

Biermann E. 1997. Grossgartach und Oberlauterbach. Interregionale Beziehungen im süddeutschen Mittelneolithikum. Deutsche Gesellschaft für Ur- und Frühgeschichte, Archäologische Berichte 8.

Bronk Ramsey C. 1995. Radiocarbon calibration and analysis of stratigraphy: the OxCal program. Radiocarbon 37(2):425-30.

Bronk Ramsey C. 2001. Development of the radiocarbon calibration program. Radiocarbon 43(2A):355-63.

Bronk Ramsey C, Higham T, Bowles A, Hedges R. 2004. Improvements to the pretreatment of bone at Oxford. Radiocarbon 46(1):155-63.

Buttler W. 1935. Ein Hinkelsteingefäß aus Köln-Lindenthal und seine Bedeutung für die Chronologie der rheinischein Bandkeramik. Germania 19:193-200.

Conscience A-C. 2001. Frühbronzezeitliche Uferdörfer aus Zürich-Mozartstrasse: eine folgenreiche Neudatierung. Jahrbuch der Schweizerischen Gesellschaft für Ur- und Frühgeschichte 84:147-57.

Denaire A. 2009. Le Néolithique moyen dans le sud de la plaine du Rhin supérieur et le nord de la FrancheComté. Les cultures de Hinkelstein, de Grossgartach et de Roessen au travers de leur production céra- mique. Monographie d'Archéologie du Grand Est 3.

Dieckmann B. 1987. Ein mittelneolithischer Fundplatz bei Mülhausen im Hegau. Stratifizierte Funde der Hinkelsteingruppe, der Stichbandkeramik und der Grossgartacher Gruppe. Archäologische Nachrichten aus Baden 38/39:20-8.

Doppler T. 2007. Une proposition de périodisation interne de la culture d'Egolzwil. Cahiers d'Archéologie Romande 108:215-26.

Dubouloz J. 2003. Datation absolue du premier Néolithique du Bassin Parisien: complément et relecture des données RRBP et VSG. Bulletin de la Société Préhistorique Française 100:671-89.

Eisenhauer U. 2002. Untersuchungen zur Siedlungs- und Kulturgeschichte des Mittelneolithikums in der Wetterau. Universitätsforschungen zur prähistorischen Archäologie 89.

Higham T, Jacobi R, Bronk Ramsey C. 2006. AMS radiocarbon dating of ancient bone using ultrafiltration. Radiocarbon 48(2):179-95.

Jadin I. 2003. Trois petits tours et puis s'en vont. La fin de la présence danubienne en Moyenne Belgique. ERAUL 109. Liège: Université de Liège. 
Jeunesse Ch. 1993. Recherches sur le Néolithique danubien du sud de la Plaine du Rhin supérieur et du Nord de la Franche-Comté [PhD dissertation]. Strasbourg: University Marc Bloch.

Jeunesse Ch. 1999. La synchronisation des séquences culturelles des bassins du Rhin, de la Meuse et de la Seine et la chronologie du Bassin parisien au Néolithique ancien et moyen (5200-4500 av. J.C.). Bulletin de la Société Préhistorique Luxembourgeoise 20-21:337-92.

Jeunesse Ch, Pétrequin P. 1997. La région de la Trouée de Belfort au Vème millénaire. Evolutions des styles céramiques et transformations techniques. In: Constantin C, Mordant D, Simonin D, editors. La culture de Cerny. Nouvelle économie, nouvelle société au Néolithique. Mémoires du Musée de Préhistoire d'Ilede-France 6:593-616.

Jeunesse Ch, Lefranc P, Denaire A. 2003. Groupe de Bischheim, origine du Michelsberg, genèse du groupe d'Entzheim. La transition entre le Néolithique moyen et le Néolithique récent dans les régions rhénanes. Cahiers de l'Association pour la Promotion de la Recherche Archéologique en Alsace 18/19.

Lefranc P. 2007. La céramique du Rubané en Alsace. Monographies d'Archéologie du grand Est 2.

Lönne P. 2003. Das Mittelneolithikum im südlichen Niedersachsen. Untersuchungen zum Kulturenkomplex Grossgartach-Planig-Friedberg-Rössen und zur Stichbandkeramik. Materialhefte zur Ur- und Frühgeschichte Niedersachsen 31.

Meier-Arendt W. 1969. Zur relativen Chronologie der Gruppen Hinkelstein und Grossgartach sowie der Rössener Kultur. Kölner Jahrbuch zur Vor- und Frühgeschichte 10.

Meier-Arendt W. 1975. Die Hinkelstein Gruppe. Römisch-Germanische Forschungen 35.

Reimer PJ, Baillie MGL, Bard E, Bayliss A, Beck JW, Bertrand CJH, Blackwell PG, Buck CE, Burr GS, Cutler KB, Damon PE, Edwards RL, Fairbanks RG,
Friedrich M, Guilderson TP, Hogg AG, Hughen KA, Kromer B, McCormac G, Manning S, Bronk Ramsey C, Reimer RW, Remmele S, Southon JR, Stuiver M, Talamo S, Taylor FW, van der Plicht J, Weyhenmeyer CE. 2004. IntCal04 terrestrial radiocarbon age calibration, 0-26 cal kyr BP. Radiocarbon 46(3):102958.

Spatz H. 1999. Das mitteneolithische Gräberfeld von Trebur, Kreis Gross-Gerau. Materialen zur Vor- und Frühgeschichte von Hessen 19.

Spatz H. 2001. Zur Verlässlichkeit von Knochendatierungen-das Beispiel Trebur, Südhessen. Prehistoria Alpina 37:273-96.

Stöckl H. 1994. Das Mittelneolithikum im nördlichen Vorland des Kaiserstuhls. In: Beier H-J. Der Rössener Horizont in Mitteleuropa. Wilkau-Hasslau. p 233-9.

Stöckli W. 1990. Der Beginn des Neolithikums in der Schweiz. In: Der ersten Bauern. Pfahlbaufunde Europas. Ausstellung Pfahlbauland in Zürich I:53-60.

Stöckli W. 2002. Absolute und relative Chronologie des Früh- und Mittelneolithikums in Westdeutschland (Rheinland und Rhein-Main-Gebiet). Basler Hefte zur Archäologie 1 .

Waton M-D, Nilles R. 1998. De la préhistoire à l'époque gallo-romaine en l'Ile Verte à Strasbourg (Bas-Rhin). Cahiers Alsaciens d'Archéologie, d'Art et d'histoire 41:25-42.

Weiner J. 1998. Drei Brunnenkästen, aber nur zwei Brunnen: Eine neue Hypothese zur Baugeschichte des Brunnens von Erkelenz-Kückhoven. Materialen zur Bodendenkmalpflege im Rheinland 11:95-112.

Zapotocka M. 1986. Die Brandgräber von Vikletice - Ein Beitrag zum chronologischen Verhältnis von Stichund Rheinbandkeramik. Archeologicke Rozhledy 38: 263-649.

Zeeb A. 1998. Die Goldberg-Gruppe im frühen Jungneolithikum Südwestdeutschlands. Ein Beitrag zur Keramik der Schulterbandgruppen. Universitätsforschungen zur prähistorischen Archäologie 48.

\section{APPENDIXES}

Table $1{ }^{14} \mathrm{C}$ dates listed for Hinkelstein, Grossgartach, Rössen, and Bischheim (Jeunesse 1993; Stöckl 1994; Waton and Nilles 1998; Biermann 1997; Jeunesse and Pétrequin 1997; Eisenhauer 2002; Jadin 2003; Jeunesse et al. 2003; Lönne 2003; Stöckli 2002; Spatz 2001).

\begin{tabular}{|c|c|c|c|c|c|c|c|c|c|}
\hline Site & Structure & Culture & Material & Lab code & $\begin{array}{l}\text { Date } \\
(\mathrm{BP})\end{array}$ & \pm & $\begin{array}{l}\text { Calib. date } \\
\text { (cal BC, } 1 \sigma)\end{array}$ & $\begin{array}{l}\text { Prob. of Prob. of } \\
\text { context contamin. }\end{array}$ & $\begin{array}{l}> \pm 100 \\
\text { yr BP }\end{array}$ \\
\hline $\begin{array}{l}\text { Mülhausen } \\
\text { "Lachen" }\end{array}$ & & HST & charcoal & $\begin{array}{l}\text { HD-9504- } \\
9244\end{array}$ & 6505 & 124 & $5610-5550$ & & $x$ \\
\hline $\begin{array}{l}\text { Mülhausen } \\
\text { "Lachen" }\end{array}$ & & HST & charcoal & $\begin{array}{l}\text { HD-9505- } \\
5245\end{array}$ & 6310 & 80 & $5470-5200$ & & \\
\hline $\begin{array}{l}\text { Mülhausen } \\
\text { "Lachen" }\end{array}$ & & HST & charcoal & $\begin{array}{l}\text { HD-9503- } \\
9243\end{array}$ & 6298 & 48 & $5315-5220$ & & \\
\hline $\begin{array}{l}\text { Mülhausen } \\
\text { "Lachen" }\end{array}$ & & HST & charcoal & $\begin{array}{l}\text { HD-9506- } \\
9245\end{array}$ & 6105 & 58 & $5210-4940$ & & \\
\hline
\end{tabular}


Table $1{ }^{14} \mathrm{C}$ dates listed for Hinkelstein, Grossgartach, Rössen, and Bischheim (Jeunesse 1993; Stöckl 1994; Waton and Nilles 1998; Biermann 1997; Jeunesse and Pétrequin 1997; Eisenhauer 2002; Jadin 2003; Jeunesse et al. 2003; Lönne 2003; Stöckli 2002; Spatz 2001). (Continued)

\begin{tabular}{|c|c|c|c|c|c|c|c|c|c|c|}
\hline Site & Structure & Culture & Material & Lab code & $\begin{array}{l}\text { Date } \\
\text { (BP) }\end{array}$ & \pm & $\begin{array}{l}\text { Calib. date } \\
\text { (cal BC, } 1 \sigma \text { ) }\end{array}$ & $\begin{array}{l}\text { Prob. of } \\
\text { context }\end{array}$ & $\begin{array}{l}\text { Prob. of } \\
\text { contamin. }\end{array}$ & $\begin{array}{l}> \pm 100 \\
\text { yr BP }\end{array}$ \\
\hline Trebur & Grab 127 & HST & bone & Oxa-5598 & 6065 & 70 & $5060-4840$ & & & \\
\hline $\begin{array}{l}\text { Bad Nauheim- } \\
\text { Steinfurth }\end{array}$ & & HST? & charcoal & HD-14135 & 6050 & 90 & $5200-4800$ & $x$ & & \\
\hline Trebur & Grab 132 & HST & bone & Oxa-5322 & 5980 & 90 & $4990-4770$ & & & \\
\hline Trebur & Grab 68 & HST & bone & Oxa-5321 & 5945 & 55 & $4900-4720$ & & & \\
\hline Zizers & & HST & hazelnut & $\begin{array}{l}\text { ETH- } \\
26644\end{array}$ & 5935 & 55 & $4900-4720$ & $x$ & & \\
\hline Zizers & & HST & hazelnut & $\begin{array}{l}\text { ETH- } \\
26643\end{array}$ & 5920 & 55 & $4850-4720$ & $x$ & & \\
\hline Trebur & Grab 108 & HST & bone & HD- 15671 & 5893 & 39 & $4800-4715$ & & $x$ & \\
\hline Trebur & Grab 113 & HST & bone & HD- 15438 & 5857 & 31 & $4780-4700$ & & $x$ & \\
\hline Trebur & Grab 52 & HST & bone & Oxa-5595 & 5840 & 55 & $4790-4610$ & & & \\
\hline Trebur & Grab 107 & HST & bone & Оха-5597 & 5835 & 55 & $4780-4610$ & & & \\
\hline Trebur & Grab 126 & HST & bone & HD-14844 & 5773 & 31 & $4690-4585$ & & $x$ & \\
\hline Trebur & Grab 67 & HST & bone & HD-15076 & 5764 & 19 & $4690-4550$ & & $x$ & \\
\hline Trebur & Grab 42 & HST & bone & HD-15227 & 5738 & 25 & $4650-4530$ & & $x$ & \\
\hline Trebur & Grab 53 & HST & bone & HD-14818 & 5586 & 26 & $4455-4365$ & & $x$ & \\
\hline Trebur & Grab 40 & HST & bone & HD-15449 & 5534 & 25 & $4450-4340$ & & $x$ & \\
\hline Trebur & Grab 120 & HST & bone & HD-14946 & 5493 & 36 & $4365-4265$ & & $x$ & \\
\hline $\begin{array}{l}\text { Edingen- } \\
\text { Neckarhausen }\end{array}$ & & HST & bone & $\mathrm{a}$ & 4918 & 70 & $3780-3640$ & & $x$ & \\
\hline $\begin{array}{l}\text { Edingen- } \\
\text { Neckarhausen }\end{array}$ & & HST & bone & $\mathrm{b}$ & 4892 & 72 & $3770-3630$ & & $\times$ & \\
\hline Schwanfeld & Haus 10 & GG & charcoal & KN-3033 & 6800 & 370 & $6100-5350$ & & $x$ & $x$ \\
\hline Schwanfeld & Haus 10 & GG & charcoal & KN-3034 & 6660 & 65 & $5640-5530$ & & $x$ & \\
\hline Gonvillars & couche XI & GG & charcoal & Gif-469 & 6250 & 300 & $5500-4800$ & & & $x$ \\
\hline Schwanfeld & Grube 800 & GG & $\begin{array}{l}\text { tempering } \\
\text { material }\end{array}$ & UtC-2323 & 6620 & 70 & $5620-5510$ & & $x$ & \\
\hline Schwanfeld & Haus 10 & GG & charcoal & KN-3035 & 6050 & 140 & $5210-4790$ & & $x$ & $x$ \\
\hline Wettolsheim & st. 32 & GG & bone & Ly-4579 & 6030 & 80 & $5030-4800$ & & & \\
\hline Schwanfeld & Haus 10 & GG & charcoal & KN-3038 & 5940 & 300 & $5250-4500$ & & $x$ & $x$ \\
\hline Hasselweiler 2 & Grube 594 & GG & charcoal & Kn-2992 & 5930 & 65 & $4900-4720$ & & & \\
\hline Trebur & Grab 17 & GG & bone & Oxa-5593 & 5910 & 90 & $4940-4680$ & & & \\
\hline Hasselweiler 2 & Grube 165 & GG & $\begin{array}{l}\text { charcoal } \\
\text { +crops }\end{array}$ & KN-2993 & 5850 & 150 & $4900-4500$ & & & $x$ \\
\hline Hasselweiler 2 & & GG & $?$ & KN-2994 & 5840 & 140 & $4900-4520$ & & & $x$ \\
\hline Trebur & Grab 58 & GG & bone & Oxa-5320 & 5840 & 55 & $4790-4610$ & & & \\
\hline Trebur & Grab 61 & GG & bone & HD-15210 & 5834 & 22 & $4770-4620$ & & $x$ & \\
\hline Hasselweiler 2 & Grube 165 & GG & charcoal & KN-2995 & 5830 & 60 & 4780-4610 & & & \\
\hline Schwanfeld & Haus 10 & GG & charcoal & KN-3039 & 5810 & 65 & $4730-4550$ & & $x$ & \\
\hline Trebur & Grab 38 & GG & bone & HD-14812 & 5782 & 20 & $4690-4610$ & & $x$ & \\
\hline Trebur & Grab 21 & GG & bone & Oxa-5594 & 5770 & 55 & $4690-4550$ & & & \\
\hline Trebur & Grab 130 & GG & bone & Oxa-5599 & 5760 & 55 & $4690-4540$ & & & \\
\hline Trebur & Grab 31 & GG & bone & HD-15465 & 5698 & 20 & $4550-4495$ & & $x$ & \\
\hline Trebur & Grab 106 & GG & bone & Oxa-5596 & 5685 & 55 & $4590-4450$ & & & \\
\hline Trebur & Grab 25 & GG & bone & HD-15314 & 5613 & 24 & $4490-4370$ & & $x$ & \\
\hline Trebur & Grab 16 & GG & bone & HD-14947 & 5602 & 25 & $4460-4370$ & & $x$ & \\
\hline Trebur & Grab 60 & GG & bone & HD-15450 & 5520 & 20 & $4370-4335$ & & $x$ & \\
\hline Trebur & Grab 122 & GG & bone & HD-15133 & 5375 & 27 & $4330-4170$ & & $x$ & \\
\hline $\begin{array}{l}\text { Moringen- } \\
\text { Großenrode }\end{array}$ & $\begin{array}{l}\text { Stelle } \\
1191\end{array}$ & GG & charcoal & KN-4415 & 6600 & 150 & $5670-5370$ & & & $x$ \\
\hline Hambach 260 & Grube 532 & GG & charcoal & KN-2947 & 6530 & 150 & $5620-5360$ & & & $x$ \\
\hline Hambach 260 & Grube 718 & GG & charcoal & KN-2948 & 6030 & 75 & $5030-4800$ & & & \\
\hline Hambach 260 & Grube 732 & GG & charcoal & KN-2949 & 5810 & 65 & $4730-4550$ & & & \\
\hline
\end{tabular}


Table $1{ }^{14} \mathrm{C}$ dates listed for Hinkelstein, Grossgartach, Rössen, and Bischheim (Jeunesse 1993; Stöckl 1994; Waton and Nilles 1998; Biermann 1997; Jeunesse and Pétrequin 1997; Eisenhauer 2002; Jadin 2003; Jeunesse et al. 2003; Lönne 2003; Stöckli 2002; Spatz 2001). (Continued)

\begin{tabular}{|c|c|c|c|c|c|c|c|c|c|c|}
\hline Site & Structure & Culture & Material & Lab code & $\begin{array}{l}\text { Date } \\
\text { (BP) }\end{array}$ & \pm & $\begin{array}{l}\text { Calib. date } \\
\text { (cal BC, } 1 \sigma)\end{array}$ & $\begin{array}{l}\text { Prob. of } \\
\text { context }\end{array}$ & $\begin{array}{l}\text { Prob. of } \\
\text { contamin. }\end{array}$ & $\begin{array}{l}> \pm 100 \\
\text { yr BP }\end{array}$ \\
\hline Schwanfeld & Haus 10 & GG & charcoal & KN-3036 & 5780 & 170 & $4840-4450$ & & $x$ & $x$ \\
\hline $\begin{array}{l}\text { Bad Nauheim- } \\
\text { Steinfurth }\end{array}$ & & GG & bone & HV-20258 & 5765 & 80 & $4710-4520$ & & & \\
\hline Schwanfeld & & GG & bone & HD-14272 & 5735 & 50 & $4680-4510$ & & & \\
\hline Strasbourg & st. 198 & GG & bone & Arc 1470 & I & I & $\begin{array}{l}4675-4150 \\
(2 \sigma)\end{array}$ & $\mathrm{x}$ & & \\
\hline $\begin{array}{l}\text { Bad Nauheim- } \\
\text { Steinfurth }\end{array}$ & & GG & bone & HV-20256 & 5665 & 80 & $4600-4370$ & & & \\
\hline $\begin{array}{l}\text { Bad Nauheim- } \\
\text { Steinfurth }\end{array}$ & & GG & bone & HV-20257 & 5560 & 100 & $4520-4270$ & & & $x$ \\
\hline Schwanfeld & Haus 10 & GG & charcoal & KN-3032 & 5420 & 140 & $4370-4050$ & & $x$ & $x$ \\
\hline Schwanfeld & Haus 10 & GG & charcoal & KN-3037 & 5400 & 300 & $4550-3800$ & & $x$ & $x$ \\
\hline $\begin{array}{l}\text { Lich-Eber- } \\
\text { stadt }\end{array}$ & & GG & bone & HV-20259 & 4980 & 100 & $3940-3650$ & & & $x$ \\
\hline Schwanfeld & Grube 800 & GG & $\begin{array}{l}\text { tempering } \\
\text { material }\end{array}$ & $\mathrm{UtC}-2324$ & 4380 & 110 & $3330-2890$ & & $\times$ & $x$ \\
\hline $\begin{array}{l}\text { Moringen- } \\
\text { Großenrode }\end{array}$ & Stelle 2 & $\begin{array}{l}\text { late GG } \\
\text { or early } \\
\text { RO }\end{array}$ & charcoal & HV-16889 & 6355 & 140 & $5490-5080$ & $x$ & & $x$ \\
\hline $\begin{array}{l}\text { Moringen- } \\
\text { Großenrode }\end{array}$ & Stelle 2 & $\begin{array}{l}\text { late GG } \\
\text { or early } \\
\text { RO }\end{array}$ & charcoal & $\mathrm{KN}-4420$ & 6240 & 200 & $5500-4950$ & $x$ & & $x$ \\
\hline $\begin{array}{l}\text { Moringen- } \\
\text { Großenrode }\end{array}$ & Stelle 2 & $\begin{array}{l}\text { late GG } \\
\text { or early } \\
\text { RO }\end{array}$ & charcoal & HV-16633 & 6115 & 75 & $5210-4940$ & $x$ & & \\
\hline $\begin{array}{l}\text { Moringen- } \\
\text { Großenrode }\end{array}$ & Stelle 2 & $\begin{array}{l}\text { late GG } \\
\text { or early } \\
\text { RO }\end{array}$ & charcoal & $\mathrm{KN}-4421$ & 6050 & 56 & $5030-4840$ & $x$ & & \\
\hline $\begin{array}{l}\text { Moringen- } \\
\text { Großenrode }\end{array}$ & $\begin{array}{l}\text { Stelle } \\
1143\end{array}$ & $\begin{array}{l}\text { late GG } \\
\text { or early } \\
\text { RO }\end{array}$ & charcoal & $\mathrm{KN}-4416$ & 5800 & 48 & $4720-4590$ & $x$ & & \\
\hline $\begin{array}{l}\text { Moringen- } \\
\text { Großenrode }\end{array}$ & Stelle 2 & $\begin{array}{l}\text { late GG } \\
\text { or early } \\
\text { RO }\end{array}$ & charcoal & KN-4411 & 5780 & 100 & $4730-4500$ & $x$ & & $x$ \\
\hline $\begin{array}{l}\text { Moringen- } \\
\text { Großenrode }\end{array}$ & Stelle 71 & $\begin{array}{l}\text { late GG } \\
\text { or early } \\
\text { RO }\end{array}$ & crops & HV-16632 & 5630 & 60 & $4530-4360$ & $x$ & & \\
\hline $\begin{array}{l}\text { Moringen- } \\
\text { Großenrode }\end{array}$ & Stelle 71 & $\begin{array}{l}\text { late GG } \\
\text { or early } \\
\text { RO }\end{array}$ & charcoal & HV-16631 & 5515 & 180 & $4550-4070$ & $x$ & & $x$ \\
\hline Inden 1 & Grube 985 & RO & charcoal & KN-I.524 & 6180 & 50 & $5220-5050$ & & & \\
\hline $\begin{array}{l}\text { Waldbillig } \\
\text { "Karelslé" }\end{array}$ & & RO & ? & Lv-2117 & 6050 & 70 & $5050-4840$ & & & \\
\hline Inden 1 & Haus 28 & RO & charcoal & KN-I.523 & 6010 & 285 & $5300-4550$ & & & $x$ \\
\hline $\begin{array}{l}\text { Moringen- } \\
\text { Großenrode } \\
\text { "Feldberg" }\end{array}$ & $\begin{array}{l}\text { Stelle } \\
1090\end{array}$ & RO & charcoal & KN-4417 & 5990 & 180 & $5250-4650$ & & & $x$ \\
\hline Inden 1 & Grube 710 & RO & charcoal & KN-I.521 & 5900 & 40 & $4830-4720$ & & & \\
\hline Diekirch & & RO & $?$ & Lv-2119 & 5890 & 100 & $4900-4610$ & & & $x$ \\
\hline $\begin{array}{l}\text { Deiringsen- } \\
\text { Ruploch }\end{array}$ & & RO & charcoal & KN-I.759 & 5890 & 75 & $4900-4680$ & & & \\
\hline Inden 1 & $\begin{array}{l}\text { Grube } \\
245 \mathrm{~A}\end{array}$ & RO & charcoal & KN-I.525 & 5880 & 60 & $4840-4680$ & & & \\
\hline Inden 3 & Grube 75 & RO & charcoal & $\mathrm{KN}-2651$ & 5870 & 60 & $4830-4620$ & & & \\
\hline Inden 1 & Stelle 6 & RO & charcoal & KN-I.190 & 5840 & 45 & $4790-4610$ & & & \\
\hline
\end{tabular}


Table $1{ }^{14} \mathrm{C}$ dates listed for Hinkelstein, Grossgartach, Rössen, and Bischheim (Jeunesse 1993; Stöckl 1994; Waton and Nilles 1998; Biermann 1997; Jeunesse and Pétrequin 1997; Eisenhauer 2002; Jadin 2003; Jeunesse et al. 2003; Lönne 2003; Stöckli 2002; Spatz 2001). (Continued)

\begin{tabular}{|c|c|c|c|c|c|c|c|c|c|}
\hline Site & Structure & Culture & Material & Lab code & $\begin{array}{l}\text { Date } \\
\text { (BP) }\end{array}$ & \pm & $\begin{array}{l}\text { Calib. date } \\
\text { (cal BC, } 1 \sigma \text { ) }\end{array}$ & $\begin{array}{l}\text { Prob. of Prob. of } \\
\text { context contamin. }\end{array}$ & $\begin{array}{l}> \pm 100 \\
\text { yr BP }\end{array}$ \\
\hline Inden 3 & Grube 2 & RO & charcoal & $\mathrm{KN}-2650$ & 5830 & 75 & $4790-4590$ & & \\
\hline Inden 3 & Grube 77 & RO & charcoal & $\mathrm{KN}-2653$ & 5830 & 65 & $4780-4610$ & & \\
\hline $\begin{array}{l}\text { Deiringsen- } \\
\text { Ruploch }\end{array}$ & & RO & $?$ & KN-583 & 5820 & 120 & $4310-4530$ & & $x$ \\
\hline Inden 3 & Grube 5 & RO & charcoal & $\mathrm{KN}-2652$ & 5820 & 60 & $4770-4590$ & & \\
\hline Hambach 471 & & RO & charcoal & KN-3050 & 5820 & 60 & $4770-4590$ & & \\
\hline Aldenhoven 1 & Grube 30 & RO & charcoal & KN-I.489 & 5820 & 55 & $4770-4590$ & & \\
\hline Inden 1 & Stelle 41 & RO & charcoal & KN-I.517 & 5820 & 50 & $4770-4600$ & & \\
\hline Inden 1 & $\begin{array}{l}\text { Grube } \\
1277\end{array}$ & RO & charcoal & KN-I.527 & 5800 & 95 & $4780-4540$ & & \\
\hline Inden 1 & Haus 23 & RO & charcoal & KN-I.330 & 5790 & 50 & $4710-4580$ & & \\
\hline $\begin{array}{l}\text { Forchheim } \\
\text { "Lindenbrun- } \\
\text { nenbuck" }\end{array}$ & Fo 12B & RO & charcoal & Kl-3037 & 5780 & 120 & $4780-4490$ & & $x$ \\
\hline Inden 1 & $\begin{array}{l}\text { Grube } \\
493 A\end{array}$ & RO & charcoal & KN-I.520 & 5750 & 50 & $4690-4540$ & & \\
\hline $\begin{array}{l}\text { Einbeck- } \\
\text { Drüber "In } \\
\text { Bereich der } \\
\text { geplanten } \\
\text { Straßen-- } \\
\text { trasse..." }\end{array}$ & Stelle 88 & RO & charcoal & HV-18871 & 5740 & 60 & $4690-4520$ & & \\
\hline Inden 1 & $\begin{array}{l}\text { Grube124 } \\
5 \mathrm{~A}\end{array}$ & RO & charcoal & KN-I.526 & 5720 & 90 & $4690-4460$ & & \\
\hline Inden 1 & $\begin{array}{l}\text { Grube } \\
1175 B\end{array}$ & RO & charcoal & KN-I.345 & 5700 & 75 & $4670-4450$ & & \\
\hline Hambach 471 & & RO & charcoal & KN-2951 & 5690 & 60 & $4610-4450$ & & \\
\hline Inden 3 & Grube 1 & RO & charcoal & $\mathrm{KN}-2649$ & 5640 & 145 & $4670-4340$ & & $x$ \\
\hline Holzhausen & & RO & charcoal & KN-I.379 & 5630 & 120 & $4600-4340$ & & $x$ \\
\hline Holzhausen & & RO & charcoal & KN-1379 & 5620 & 120 & $4620-4340$ & & $x$ \\
\hline Aldenhoven 1 & & RO & charcoal & KN-I.346 & 5540 & 115 & $4520-4250$ & & $x$ \\
\hline $\begin{array}{l}\text { Moringen- } \\
\text { Großenrode } \\
\text { "Feldberg" }\end{array}$ & Stelle 81 & RO & $?$ & HV-16887 & 5500 & 250 & $4650-4000$ & & $x$ \\
\hline Gondenans & $\begin{array}{l}\text { niveau } \\
\mathrm{IXb}\end{array}$ & RO & charcoal & Ly-335 & 5490 & 140 & $4500-4050$ & & $x$ \\
\hline Gonvillars & couche $\mathrm{Xb}$ & $\begin{array}{l}\mathrm{RO} \text { or } \\
\mathrm{BI}\end{array}$ & $\begin{array}{l}\text { charcoal } \\
\text { or crops? }\end{array}$ & Gif-468 & 5380 & 250 & $4500-3900$ & $x$ & $x$ \\
\hline $\begin{array}{l}\text { Dettelbach- } \\
\text { Schernau }\end{array}$ & St. $36 \mathrm{G}$ & $\begin{array}{l}\text { RO or } \\
\mathrm{BI}\end{array}$ & charcoal & $\mathrm{KN}-2112$ & 5750 & 75 & $4690-4500$ & $x$ & \\
\hline $\begin{array}{l}\text { Dettelbach- } \\
\text { Schernau }\end{array}$ & St. $36 \mathrm{G}$ & $\begin{array}{l}\mathrm{RO} \text { or } \\
\mathrm{BI}\end{array}$ & charcoal & $\mathrm{KN}-2360$ & 5730 & 130 & $4690-4460$ & $x$ & $x$ \\
\hline $\begin{array}{l}\text { Dettelbach- } \\
\text { Schernau }\end{array}$ & St. 38.1 & $\begin{array}{l}\mathrm{RO} \text { or } \\
\mathrm{BI}\end{array}$ & charcoal & $\mathrm{KN}-2401$ & 5720 & 110 & $4680-4480$ & $x$ & $x$ \\
\hline Wahlitz & & $\begin{array}{l}\mathrm{RO} \text { or } \\
\mathrm{BI}\end{array}$ & crops & GrN-433 & 5300 & 200 & $4350-3800$ & $x$ & $x$ \\
\hline Ittre & fosse 29 & BI & charcoal & Lv-1575 & 5950 & 150 & $5050-4610$ & & $x$ \\
\hline Kärlich & & BI & charcoal & GrN-6347 & 5685 & 95 & $4680-4400$ & & \\
\hline $\begin{array}{l}\text { Dettelbach- } \\
\text { Schernau }\end{array}$ & St. 77.5 & BI & charcoal & $\mathrm{KN}-2363$ & 5660 & 50 & $4550-4400$ & & \\
\hline Schwalheim & & BI & charcoal & KN-I.568 & 5660 & 40 & $4540-4455$ & & \\
\hline Ittre & fosse 37 & $\mathrm{BI}$ & charcoal & Lv-1576 & 5640 & 120 & $4610-4350$ & & $x$ \\
\hline Guntersblum & & BI & $?$ & Fra-96 & 5640 & 100 & $4590-4350$ & & $x$ \\
\hline Guntersblum & & BI & $?$ & Fra-97 & 5630 & 100 & $4560-4350$ & & $x$ \\
\hline
\end{tabular}


Table $1{ }^{14} \mathrm{C}$ dates listed for Hinkelstein, Grossgartach, Rössen, and Bischheim (Jeunesse 1993; Stöckl 1994; Waton and Nilles 1998; Biermann 1997; Jeunesse and Pétrequin 1997; Eisenhauer 2002; Jadin 2003; Jeunesse et al. 2003; Lönne 2003; Stöckli 2002; Spatz 2001). (Continued)

\begin{tabular}{|c|c|c|c|c|c|c|c|c|c|}
\hline Site & Structure & Culture & Material & Lab code & $\begin{array}{l}\text { Date } \\
(\mathrm{BP})\end{array}$ & \pm & $\begin{array}{l}\text { Calib. date } \\
(\text { cal BC, } 1 \sigma)\end{array}$ & $\begin{array}{l}\text { Prob. of Prob. of } \\
\text { context contamin. }\end{array}$ & $\begin{array}{l}> \pm 100 \\
\text { yr BP }\end{array}$ \\
\hline $\begin{array}{l}\text { Berry-au- } \\
\text { Bac "LCM" }\end{array}$ & & BI & charcoal & Ly-2326 & 5530 & 320 & $4500-3750$ & & $x$ \\
\hline $\begin{array}{l}\text { Dettelbach- } \\
\text { Schernau }\end{array}$ & St. 77.4 & BI & charcoal & $\mathrm{KN}-2361$ & 5470 & 85 & $4450-4230$ & & \\
\hline $\begin{array}{l}\text { Berry-au- } \\
\text { Bac "LCM" }\end{array}$ & & BI & charcoal & Ly-2371 & 5340 & 130 & $4330-4040$ & & $x$ \\
\hline Ittre & fosse 39 & BI & charcoal & Lv-1577 & 5330 & 200 & $4370-3940$ & & $x$ \\
\hline $\begin{array}{l}\text { Berry-au-Bac } \\
\text { "LCM" }\end{array}$ & & BI & charcoal & Ly-2370 & 5330 & 130 & $4330-4040$ & & $x$ \\
\hline Ittre & fosse 48 & BI & charcoal & Lv-1619 & 5180 & 100 & $4230-3800$ & & $x$ \\
\hline $\begin{array}{l}\text { Berry-au-Bac } \\
\text { "LCM" }\end{array}$ & & BI & charcoal & Ly-2329 & 5100 & 160 & $4050-3690$ & & $x$ \\
\hline
\end{tabular}

Table $2{ }^{14} \mathrm{C}$ dates listed for the end of Linearbandkeramik in the Paris Basin, North Rhineland-Westphalia, the Middle Rhine, the Palatinate, and the Neckar Valley (Stöckli 2002; Dubouloz 2003; Jadin 2003).

\begin{tabular}{|c|c|c|c|c|c|c|c|}
\hline Site & Structure & Material & Lab code & $\begin{array}{l}\text { Date } \\
\text { (BP) }\end{array}$ & \pm & $\begin{array}{ll}\text { Date (cal BC, } & \text { Prob. of con- } \\
1 \sigma) & \text { tamination }\end{array}$ & $\begin{array}{l}> \pm 100 \\
\text { yr BP }\end{array}$ \\
\hline Balloy & fosse 1 & bone & Oxa-4078 & 6180 & 90 & $5290-5000$ & \\
\hline Balloy & fosse 8 & bone & Ly-5542 & 5680 & 60 & $4600-4450$ & \\
\hline Balloy & fosse 13 & bone & Ly-5541 & 5770 & 60 & $4690-4540$ & \\
\hline Balloy & fosse 17 & bone & Ly-5540 & 5720 & 85 & $4690-4460$ & \\
\hline Balloy & sép. 20 & bone & Ly-5883 & 6220 & 160 & $5360-4980$ & $x$ \\
\hline Barbey & & bone & Ly-5880 & 5670 & 110 & $4660-4360$ & $x$ \\
\hline $\begin{array}{l}\text { Berry-au-Bac "La Croix } \\
\text { Maigret" }\end{array}$ & fosse 124 & bone & Ly-62327 & 6030 & 130 & $5210-4770$ & $x$ \\
\hline $\begin{array}{l}\text { Berry-au-Bac "Le Chemin } \\
\text { de la Pêcherie"" }\end{array}$ & fosse 201 & hazelnut & Oxa-6686 & 6080 & 45 & $5190-4910$ & \\
\hline $\begin{array}{l}\text { Bucy-le-Long "La fosse- } \\
\text { Tounise" }\end{array}$ & fosse 23 & bone & GiF-A97057 & 5900 & 90 & $4910-4620$ & \\
\hline $\begin{array}{l}\text { Bucy-le-Long “La Fosse- } \\
\text { Tounise" }\end{array}$ & fosse 159 & bone & Ly-6478 & 5870 & 105 & $4880-4590$ & $x$ \\
\hline $\begin{array}{l}\text { Bucy-le-Long "La Héron- } \\
\text { nière" }\end{array}$ & fosse 124 & crops & Oxa-6642 & 6250 & 55 & $5310-5070$ & \\
\hline $\begin{array}{l}\text { Bucy-le-Long "La Héron- } \\
\text { nière" }\end{array}$ & fosse 124 & bone & Orstom-1082 & 5780 & 70 & $4710-4540$ & \\
\hline Colombelles & & charcoal & Colombelles1 & 6150 & 40 & $5210-5040$ & \\
\hline Colombelles & & charcoal & Colombelles2 & 6150 & 40 & $5210-5040$ & \\
\hline Colombelles & & charcoal & Colombelles3 & 6140 & 40 & $5210-5000$ & \\
\hline Cuiry-lès-Chaudardes & fosse 230 & bone & Ly-1736 & 6450 & 160 & $5610-5220$ & $x$ \\
\hline Cuiry-lès-Chaudardes & fosse 246 & bone & Ly-1737 & 6220 & 230 & $5500-4850$ & $x$ \\
\hline Cuiry-lès-Chaudardes & fosse 311 & bone & Ly-2331 & 6000 & 120 & $5040-4720$ & $x$ \\
\hline Cuiry-lès-Chaudardes & fosse 357 & bone & Ly-2333 & 5980 & 110 & $5000-4720$ & $\times$ \\
\hline Cuiry-lès-Chaudardes & fosse 295 & bone & Ly-2321 & 5960 & 170 & $5200-4600$ & $x$ \\
\hline Cuiry-lès-Chaudardes & fosse 375 & bone & Ly-2336 & 5960 & 150 & $5060-4620$ & $x$ \\
\hline Cuiry-lès-Chaudardes & fosse 175 & bone & Ly-1829 & 5930 & 190 & $5040-4550$ & $x$ \\
\hline Cuiry-lès-Chaudardes & $\begin{array}{l}\text { fosse } 324 / \\
325\end{array}$ & bone & Ly-2330 & 5910 & 130 & $4950-4610$ & $x$ \\
\hline Cuiry-lès-Chaudardes & fosse 27 & bone & Ly-1827 & 5880 & 300 & $5250-4400$ & $x$ \\
\hline Cuiry-lès-Chaudardes & fosse $378-1$ & bone & Ly-2335 & 5840 & 140 & $4900-4520$ & $x$ \\
\hline Cuiry-lès-Chaudardes & fosse $378-2$ & bone & Ly-2551 & 5870 & 175 & $4950-4520$ & $x$ \\
\hline Cuiry-lès-Chaudardes & fosse 321 & bone & Ly-2332 & 5800 & 170 & $4850-4450$ & $x$ \\
\hline Cuiry-lès-Chaudardes & 382 & bone & Ly-2552 & 5730 & 170 & $4770-4360$ & $x$ \\
\hline
\end{tabular}


Table $2{ }^{14} \mathrm{C}$ dates listed for the end of Linearbandkeramik in the Paris Basin, North Rhineland-Westphalia, the Middle Rhine, the Palatinate, and the Neckar Valley (Stöckli 2002; Dubouloz 2003; Jadin 2003). (Continued)

\begin{tabular}{|c|c|c|c|c|c|c|c|c|}
\hline Site & Structure & Material & Lab code & $\begin{array}{l}\text { Date } \\
\text { (BP) }\end{array}$ & \pm & $\begin{array}{l}\text { Date (cal BC, } \\
1 \sigma)\end{array}$ & $\begin{array}{l}\text { Prob. of con- } \\
\text { tamination }\end{array}$ & $\begin{array}{l}> \pm 100 \\
\mathrm{yr} \mathrm{BP}\end{array}$ \\
\hline Champlay & fosse 2 & bone & Ly-9511 & 5920 & 40 & $4840-4720$ & & \\
\hline Champlay & fosse 4 & bone & Ly-9510 & 5850 & 50 & $4790-4610$ & & \\
\hline Compiègne & fosse 2 & bone & Ly-2716 & 6080 & 110 & $5210-4840$ & & $x$ \\
\hline Compiègne & fosse 4 & bone & Ly-2720 & 5950 & 120 & $5000-4690$ & & $x$ \\
\hline Compiègne & fosse 3 & bone & Ly-2717 & 5920 & 260 & $5250-4450$ & & $x$ \\
\hline Menneville & fosse 13 & bone & Ly-1735 & 6200 & 190 & $5370-4910$ & & $x$ \\
\hline Menneville & fosse 1 & bone & Ly-1734 & 6140 & 190 & $5300-4840$ & & $x$ \\
\hline Menneville & fosse 13 & bone & Ly-2324 & 6110 & 140 & $5220-4840$ & & $x$ \\
\hline Menneville & fosse 40 & $\begin{array}{l}\text { crops }+ \\
\text { pitch }\end{array}$ & $0 \times a-6644$ & 6040 & 55 & $5000-4840$ & $x$ & \\
\hline Menneville & fosse 19 & bone & Ly-2322 & 6030 & 130 & $5210-4770$ & & $x$ \\
\hline Menneville & fosse 40 & noisette & Oxa-6646 & 6025 & 55 & $4990-4840$ & & \\
\hline Menneville & fosse 39 & $\begin{array}{l}\text { crops }+ \\
\text { pitch }\end{array}$ & Oxa-6645 & 5985 & 55 & $4940-4790$ & $x$ & \\
\hline Menneville & fosse 39 & bone & Ly-2323 & 5860 & 190 & $4950-4350$ & & $x$ \\
\hline Passy-sur-Yone & fosse 6 & bone & Ly-3447 & 6400 & 180 & $5560-5080$ & & $x$ \\
\hline Passy-sur-Yone & fosse 6 & bone & Ly-8823 & 6065 & 55 & $5050-4850$ & & \\
\hline Saint-Juliens-du-Saut & fosse 28 & bone & 537(Oxa) & 6055 & 55 & $5040-4850$ & & \\
\hline Aldenhoven-Niedermerz 3 & Grab 31 & charcoal & $\mathrm{KN}-2125$ & 5830 & 150 & $4850-4490$ & & $x$ \\
\hline Aldenhoven-Niedermerz 3 & Grab 26 & charcoal & KN-I.531 & 6070 & 95 & $5210-4840$ & & \\
\hline Aldenhoven-Niedermerz 3 & Grab 34 & charcoal & $\mathrm{KN}-2286$ & 6180 & 120 & $5300-4990$ & & $x$ \\
\hline Aldenhoven-Niedermerz 3 & Grab 23 & charcoal & KN-I.530 & 6190 & 65 & $5230-5040$ & & \\
\hline Aldenhoven-Niedermerz 3 & Grab 81 & charcoal & $\mathrm{KN}-2284$ & 6190 & 100 & $5300-5010$ & & $x$ \\
\hline Aldenhoven-Niedermerz 3 & Grab 57 & charcoal & $\mathrm{KN}-2124$ & 6210 & 60 & $5300-5060$ & & \\
\hline Aldenhoven-Niedermerz 3 & Grab 2 & charcoal & $\mathrm{KN}-2285$ & 6280 & 185 & $5470-5040$ & & $x$ \\
\hline Hilzingen & Grube 375 & charcoal & HD-9910/9751 & 5800 & 110 & $4790-4530$ & & $x$ \\
\hline Hilzingen & Grube 370 & charcoal & HD-9906/9733 & 5990 & 180 & $5250-4650$ & & $x$ \\
\hline Hilzingen & Grube 338 & crops & HD-9913/9765 & 6000 & 50 & $4950-4800$ & & \\
\hline Hilzingen & Grube 3842 & charcoal & HD-9907/9734 & 6100 & 95 & $5210-4910$ & & \\
\hline Hilzingen & Grube 395 & charcoal & HD-9912/9760 & 6125 & 85 & $5210-4960$ & & \\
\hline Hilzingen & Grube 338 & charcoal & HD-9914/9766 & 6130 & 45 & $5210-4990$ & & \\
\hline Hilzingen & Grube 3902 & charcoal & HD-9909/9750 & 6130 & 110 & $5220-4930$ & & $x$ \\
\hline Hilzingen & Grube 338 & charcoal & HD-9904/9731 & 6160 & 50 & $5210-5050$ & & \\
\hline Hilzingen & Grube 335 & charcoal & HD-9905/9732 & 6210 & 100 & $5300-5050$ & & $x$ \\
\hline Hilzingen & Grube 334 & charcoal & HD-9911/9752 & 6230 & 80 & $5310-5060$ & & \\
\hline Hilzingen & Grube 3663 & charcoal & HD-9908/9748 & 6270 & 80 & $5330-5070$ & & \\
\hline Herxheim & $\begin{array}{l}\text { Graben } \\
281-14\end{array}$ & bone & Vera-1826 & 6145 & 35 & $5210-5020$ & & \\
\hline Herxheim & $\begin{array}{l}\text { Graben } \\
281-117\end{array}$ & bone & Vera-1827 & 6165 & 40 & $5210-5050$ & & \\
\hline Herxheim & $\begin{array}{l}\text { Graben } \\
282-7\end{array}$ & bone & Vera-1828 & 6190 & 30 & $5220-5070$ & & \\
\hline Herxheim & $\begin{array}{l}\text { Graben } \\
282-86\end{array}$ & bone & Vera-1829 & 6995 & 35 & $5980-5840$ & $x$ & \\
\hline Herxheim & Grube 296 & bone & Vera-1830 & 6195 & 35 & $5220-5070$ & & \\
\hline Langweiler 2 & Grube 785 & charcoal & KN-2298 & 5990 & 140 & $5190-4700$ & & $x$ \\
\hline Langweiler 2 & Grube 989 & charcoal & KN-I.910 & 6070 & 120 & $5210-4830$ & & $x$ \\
\hline Langweiler 2 & Grube 989 & charcoal & KN-I.911 & 6070 & 120 & $5210-4830$ & & $x$ \\
\hline Langweiler 2 & $\begin{array}{l}\text { Grube } 800- \\
3\end{array}$ & crops & Оха- 2898 & 6170 & 60 & $5220-5040$ & & \\
\hline Langweiler 2 & $\begin{array}{l}\text { Grube 100- } \\
6\end{array}$ & crops & Оха-2896 & 6190 & 60 & $5220-5050$ & & \\
\hline Langweiler 2 & Grube 160 & charcoal & $\mathrm{KN}-2300$ & 6200 & 90 & $5300-5040$ & & \\
\hline Langweiler 2 & $\begin{array}{l}\text { Grube 785- } \\
14\end{array}$ & crops & Oxa-2897 & 6230 & 69 & $5300-5070$ & & \\
\hline
\end{tabular}


Table $2{ }^{14} \mathrm{C}$ dates listed for the end of Linearbandkeramik in the Paris Basin, North Rhineland-Westphalia, the Middle Rhine, the Palatinate, and the Neckar Valley (Stöckli 2002; Dubouloz 2003; Jadin 2003). (Continued)

\begin{tabular}{|c|c|c|c|c|c|c|c|c|}
\hline Site & Structure & Material & Lab code & $\begin{array}{l}\text { Date } \\
\text { (BP) }\end{array}$ & \pm & $\begin{array}{l}\text { Date (cal BC, } \\
1 \sigma)\end{array}$ & $\begin{array}{l}\text { Prob. of con- } \\
\text { tamination }\end{array}$ & $\begin{array}{l}> \pm 100 \\
\text { yr BP }\end{array}$ \\
\hline Langweiler 2 & Grube 284 & charcoal & $\mathrm{KN}-2301$ & 6340 & 70 & $5470-5220$ & & \\
\hline Langweiler 3 & Grube 0017 & charcoal & KN-I.665 & 6180 & 60 & $5220-5050$ & & \\
\hline Langweiler 8 & $\begin{array}{l}\text { Grube } \\
3813-7\end{array}$ & crops & Оха-2900 & 6160 & 60 & $5220-5040$ & & \\
\hline Langweiler 8 & Grube 2677 & charcoal & KN-2988 & 6250 & 190 & $5470-4980$ & & $x$ \\
\hline Langweiler 8 & $\begin{array}{l}\text { Grube } \\
2799-16\end{array}$ & crops & Оха-2899 & 6290 & 70 & $5370-5200$ & & \\
\hline Langweiler 8 & Grube 412 & charcoal & KN-2990 & 6300 & 95 & $5470-5070$ & & \\
\hline Langweiler 8 & Grube 3961 & charcoal & KN-2985 & 6340 & 160 & $5480-5070$ & & $x$ \\
\hline Langweiler 8 & Grube 4521 & charcoal & KN-2991 & 6380 & 160 & $5520-5080$ & & $x$ \\
\hline Langweiler 8 & Grube 3930 & charcoal & KN-2981 & 6760 & 150 & $5800-5530$ & & $x$ \\
\hline Langweiler 9 & $\begin{array}{l}\text { Grube 616- } \\
6\end{array}$ & charcoal & KN-2698 & 5930 & 145 & $5000-4610$ & & $\times$ \\
\hline Langweiler 9 & Grube 561 & charcoal & $\mathrm{KN}-2691$ & 6010 & 150 & $5210-4710$ & & $\times$ \\
\hline Langweiler 9 & Grube 1061 & charcoal & $\mathrm{KN}-2488$ & 6210 & 65 & $5300-5050$ & & \\
\hline Langweiler 9 & $\begin{array}{l}\text { Grube 146- } \\
108\end{array}$ & crops & Оха-2901 & 6250 & 60 & $5310-5070$ & & \\
\hline Langweiler 9 & Grube 1431 & charcoal & KN-2697 & 6370 & 210 & $5530-5060$ & & $x$ \\
\hline Langweiler 9 & Grube 1062 & charcoal & KN-2496 & 6520 & 155 & $5620-5340$ & & $x$ \\
\hline Langweiler 9 & Grube 1301 & charcoal & KN-2694 & 6620 & 150 & $5710-5460$ & & $x$ \\
\hline Langweiler 9 & Grube 1090 & charcoal & KN-2695 & 7090 & 135 & $6080-5800$ & & $\times$ \\
\hline Langweiler 9 & Grube 561 & charcoal & KN-2693 & 7130 & 155 & $6210-5840$ & & $x$ \\
\hline Maring-Noviand & Oxa-6651 & crops & Oxa-6651 & 6060 & 55 & $5050-4850$ & & \\
\hline Müddersheim & & charcoal & H-924a/1393 & 6150 & 90 & $5220-4980$ & & \\
\hline Müddersheim & & charcoal & KN-I.006 & 6210 & 50 & $5290-5060$ & & \\
\hline Müddersheim & & charcoal & $\mathrm{H}-924 \mathrm{~b} / 1121$ & 6330 & 80 & $5470-5210$ & & \\
\hline Talheim & & bone & HD-8827/8606 & 5960 & 80 & $4950-4720$ & & \\
\hline Talheim & & bone & HD-8828/8607 & 6045 & 60 & $5020-4840$ & & \\
\hline Stuttgart-Mühlhausen & Grab 26 & bone & HD-7935/7761 & 5910 & 50 & $4840-4720$ & & \\
\hline Stuttgart-Mühlhausen & Grab 26 & bone & HD-7974/7762 & 5950 & 60 & $4930-4720$ & & \\
\hline Stuttgart-Mühlhausen & Grab 21 & bone & HD-8099/8006 & 5970 & 70 & $4950-4770$ & & \\
\hline Stuttgart-Mühlhausen & Grab 40 & bone & HD-7949/7757 & 5990 & 40 & $4940-4800$ & & \\
\hline Stuttgart-Mühlhausen & Grab 21 & bone & HD-8097/8005 & 5990 & 60 & $4950-4790$ & & \\
\hline Stuttgart-Mühlhausen & Grab 6 & bone & HD-8096/8004 & 6000 & 55 & $4960-4800$ & & \\
\hline Stuttgart-Mühlhausen & Grab 40 & bone & HD-7963/7759 & 6010 & 50 & $4980-4830$ & & \\
\hline Stuttgart-Mühlhausen & Grab 36 & bone & HD-7920/7766 & 6040 & 50 & $5000-4840$ & & \\
\hline Stuttgart-Mühlhausen & Grab 6 & bone & HD-8087/8003 & 6040 & 60 & $5010-4840$ & & \\
\hline Stuttgart-Mühlhausen & Grab 47 & bone & HD-7994/7770 & 6050 & 60 & $5030-4840$ & & \\
\hline Stuttgart-Mühlhausen & Grab 21 & bone & HD-8152/8007 & 6070 & 40 & $5050-4910$ & & \\
\hline Stuttgart-Mühlhausen & Grab 40 & bone & HD-7918/7758 & 6090 & 50 & $5200-4930$ & & \\
\hline Stuttgart-Mühlhausen & Grab 47 & bone & HD-7993/7769 & 6100 & 60 & $5210-4930$ & & \\
\hline Stuttgart-Mühlhausen & Grab 26 & bone & HD-8031/7760 & 6100 & 70 & $4210-4930$ & & \\
\hline Stuttgart-Mühlhausen & Grab 79 & bone & HD-7977/7763 & 6130 & 45 & $5210-4990$ & & \\
\hline Stuttgart-Mühlhausen & Grab 36 & bone & HD-7980/7768 & 6135 & 90 & $5220-4960$ & & \\
\hline Stuttgart-Mühlhausen & Grab 36 & bone & HD-7950/7767 & 6140 & 100 & $5220-4950$ & & $x$ \\
\hline Stuttgart-Mühlhausen & Grab 47 & bone & HD-7995/7771 & 6190 & 45 & $5220-5060$ & & \\
\hline Stuttgart-Mühlhausen & Grab 79 & bone & HD-7979/7765 & 6210 & 45 & $5290-5060$ & & \\
\hline Stuttgart-Mühlhausen & Grab 79 & bone & HD-7978/7764 & 6220 & 45 & $5300-5070$ & & \\
\hline
\end{tabular}

